\title{
The Middle Jurassic Alpine Tethyan Unconformity and the Eastern Sardinia - Corsica Jurassic High: A sedimentary and regional analysis
}

\author{
L.G. Costamagna \\ Dipartimento di Scienze Chimiche e Geologiche, Università di Cagliari, Via Trentino 51, 09127 Cagliari (Italy) \\ e-mail address: lucakost@unica.it
}

Received: 15 February 2016 / Accepted: 18 November 2016 / Available online: 20 December 2016

\begin{abstract}
Investigations performed along the Middle Jurassic Alpine Tethyan unconformity surface of E Sardinia evidenced an elaborate surface that developed over older Late Paleozoic to Triassic rocks. This surface is covered by the Middle Jurassic Genna Selole Fm, which has different sedimentological and petrographical characteristics and thicknesses according to its location and the morphology and evolution of the lower substrate.

An analysis of the unconformity and the rocks located above and below it revealed that a tectonic high emerged early during the Middle Jurassic from E Sardinia to Corsica in response to the extensional tectonics leading to the Alpine Tethys opening. This high was almost immediately fragmented in secondary blocks, and an irregular morphology of minor lows and highs thus formed upon it. The high was, on the whole, subjected to strong erosion. Its deposits accumulated along the rims of the high and in the lows of its surface, smoothing the landscape and preparing it for the marine transgression that followed. The tectonic high rapidly collapsed starting from its North side as show the older age of the marine deposits first investigated.

A similar rise-and-collapse tectosedimentary evolution can be seen in some of the W Mediterranean domains next to the Sardinia-Corsica block. Indeed, they are all related to the Alpine Tethys opening and may mark a discontinuous high separating the Paleoeuropa from the Tethyan domain. Consequently, a comparison with all of these domains has been attempted by trying to set the Sardinia-Corsica block in this extensional margin scenario.
\end{abstract}

Keywords: Alpine Tethys, Unconformity, Jurassic, Paleogeography, Sedimentology, Eastern Sardinia-Corsica Tectonic high

Resumen

Investigaciones llevadas a cabo en la superficie discordante del Jurásico Medio del Tetis alpino evidencia que esta superficie está muy elaborada y se desarrolló sobre rocas que abarcan desde un registro Paleozoico Superior a Triásico. Esta superficie está cubierta por la Fm Genna Selode, de edad Jurásico Medio, que tiene diferentes características sedimentológicas y petrológicas y una potencia que depende de su localización y la morfología y evolución del substrato inferior.

Un análisis de esta discordancia y de las rocas localizadas por encima y debajo de la misma revela que hubo un importante alto tectónico in etapas iniciales del Jurásico Medio que afectaba desde el E de Cerdeña a Córcega en respuesta a una tectónica extensional relacionada con la apertura del Tetis alpino. Esta área elevada fue rápidamente fragmentada en bloques desarrollándose una morfología de zonas altas y deprimidas previa a la transgresión marina que llegó seguidamente. Por los datos que muestran los primeros registros marinos se puede deducir que la fragmentación del citado alto tectónico se inició por su parte norte. Una evolución similar en zonas altas y bajas puede observarse igualmente en otras zonas del Mediterráneo occidental próximas al bloque de Córcega-Cerdeña. De hecho, todas ellas están relacionadas con la apertura del Tetis alpino y pueden marcar un alto discontinuo que separa Paleoeuropa del dominio del Tetis. Consecuentemente, una comparación de todos estos dominios ha permitido situar el bloque Córcega-Cerdeña en el escenario de este margen extensional.

Palabras clave: Tetis alpino, Discordancia, Jurásico, Paleogeografía, Sedimentología, Alto Tectónico del Este de Córcega-Cerdeña

\section{Introduction}

A Middle Jurassic to Cretaceous sedimentary cover, about $1000 \mathrm{~m}$ thick crops out in E Sardinia (nearly $170 \mathrm{~km}$, Fig. 1) (Amadesi et al., 1960; Assorgia et al., 1974; Assorgia and
Gandolfi, 1975; Dieni and Massari, 1985a; Costamagna and Barca, 2004; Costamagna et al., 2007; Jadoul et al., 2010; Casellato et al., 2012; Costamagna, 2013a; Dieni et al., 2013). This cover tectonically undisturbed rests over an unconformity that is Bajocian in age and forms the base of the 
Middle Jurassic succession (Dieni et al., 1983). This unconformity, named the "Alpine Tethyan unconformity" herein, tops Variscan Cambrian to Early Carboniferous metamorphic rocks (Carmignani et al., 1994, 2001), and less commonly Triassic (Costamagna and Barca, 2002) and Permian (Cassinis and Ronchi, 2002) sedimentary deposits. The age and causes of this unconformity is coeval to the Jurassic opening of the Alpine Tethys in the W Mediterranean area (Abbate et al., 1986; Bernoulli and Jenkyns, 1974; Stampfli, 2000) an thus can be considered related to it.

The goal of this paper is to investigate the evolution and significance of the Alpine Tethyan unconformity in Sardinia, and to unravel the evolving paleoenvironments and paleomorphology of the transgressed Middle Jurassic landscape. The unconformity is closely related to the rise and development of the E Sardinia - Corsica high, which is a Jurassic structural feature of regional importance. Stratigraphic, sedimentological and petrographical investigations have been performed: A) on the unconformity to define its areal and geometric characteristics; B) on the Variscan basement and Triassic rocks found below the unconformity; and C) on the Middle Jurassic Genna Selole Fm (Dieni et al., 1983) resting upon it to highlight the features, lifetime and areal extension of the E Sardinia - Corsica high. More than seventy stratigraphic sections across the unconformity have been sampled and analyzed (Fig. 1). This dataset served to reconstruct the evolution of the E Sardinia-Corsica high by highlighting the influence of tectonics on sedimentation and evidencing the morphological profile of E Sardinia in early Middle Jurassic times. Additionally, this produced a relative clear chronology of the development stages of the high that range from a continental (erosive to depositional) landscape to a transitional environment and, finally, to the marine Tethyan transgression. This study has been accomplished using physical stratigraphy, sedimentological features of the sections, and the limited biostratigraphical data. In fact, the paleontological content (Dieni et al., 1983; Dieni et al., 2013 and references therein; Scanu et al., 2014) does not have good enough stratigraphic detail to enable a minute subdivision into Bajocian and Bathonian times (Del Rio, pers. comm.): this would be necessary because of this is the time interval in which was deposited the continental to transitional Genna Selole Fm that starts the new Jurassic depositional cycle over the Variscan basement. Moreover, Jadoul et al. (2010) also noted that "the scarce biostratigraphic control does not permit a precise chronostratigraphic assessment of the marine transgression ruling the start of the carbonate sedimentation in the investigated area."

\section{Geological setting}

The E Sardinia Variscan basement consists of several superposed tectonic units (Carmignani et al., 1994; 2001) with a metamorphic grade that grows from $\mathrm{S}$ to $\mathrm{N}$ from the greenschists facies to the amphibolite facies. According to the most recent findings (Funedda, pers. comm.), this Cambrian to Early Carboniferous succession is up to 1000 to $1200 \mathrm{~m}$ thick. The pre- Middle Jurassic surface of the Variscan basement may be locally affected by processes of lateritization (Marini, 1984).

Remains of the Late Carboniferous to Permian molasse basins rarely overlie the Variscan basement unconformably (Cassinis and Ronchi, 2002), forming a more than $300 \mathrm{~m}$ thick succession that locally (SE Sardinia) also includes thin Middle Triassic deposits ( $<50 \mathrm{~m}$ ) (Costamagna and Barca, 2002).

The Jurassic succession (Fig. 2) overlies a regional unconformity (see below) and starts with continental conglomerates and sandstones before passing into marine carbonates of the Genna Selole Fm (Bajocian-Bathonian) (Del Rio, 1976, 1984; Dieni et al., 1983; Dieni and Massari, 1985a; Costamagna and Barca, 2004; Costamagna et al., 2007; Costamagna, 2015). This unit is up to $80 \mathrm{~m}$ thick in the SE of the island, and is composed of: 1) the Laconi-Gadoni lithofacies, which
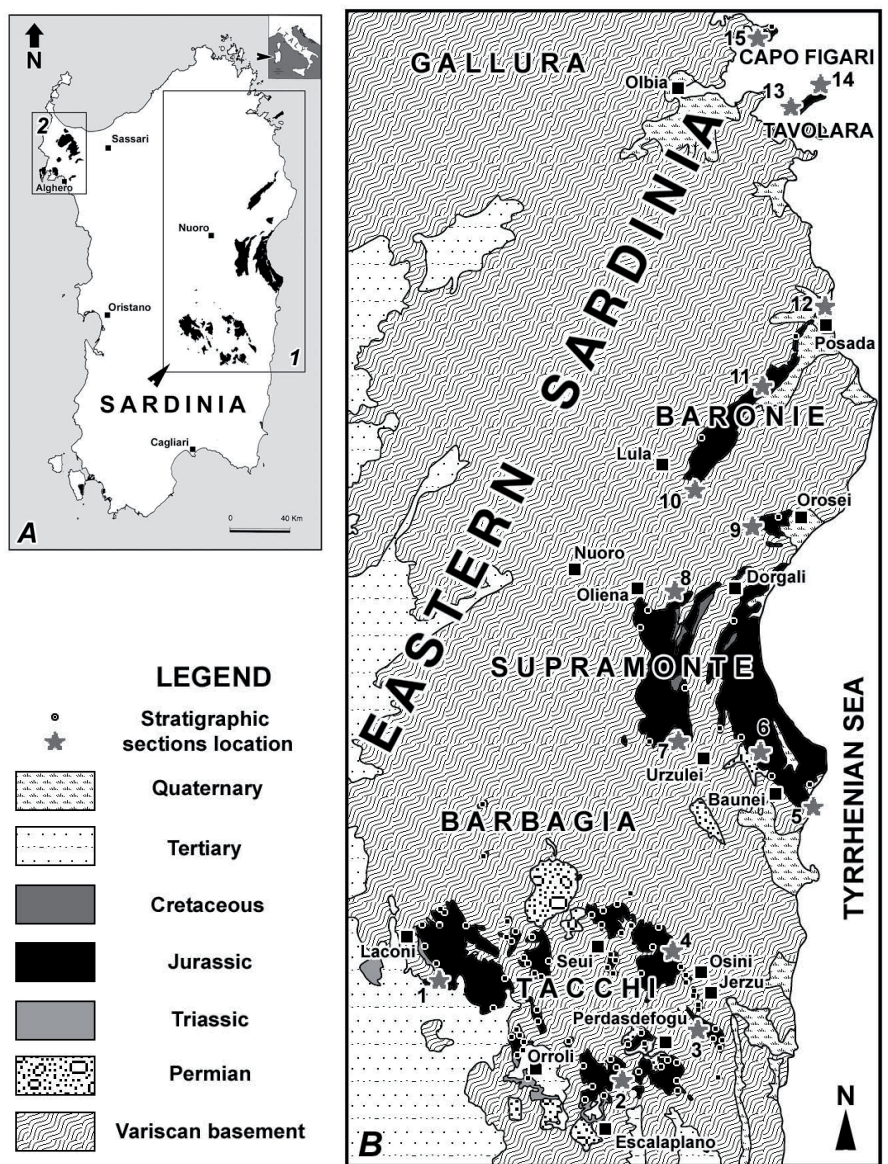

Fig. 1.- A) Localization of the studied areas: Jurassic terrains are marked in black. 1: eastern Sardinia; 2: nortwestern Sardinia. B) Geological setting of Eastern Sardinia and location of the investigated stratigraphic sections. The main sections described in the text and illustrated in figure 7 are evidenced by a star and numbered. The other sections are evidenced by a dot. 1: Pitzu Rubiu Quarry; 2: S'Arcu de Is Fronestas; 3) S'Arcu Sa Perdia; 4) Bruncu Matzeu; 5) Monte Oro; 6) Dispensa Selole; 7) Punta Orotecannas; 8) Gologone; 9) Monte Tuttavista; 10) Su Ercone; 11) Punta Cupetti; 12) Torre di Posada; 13) Punta la Mandria; 14) Punta Spalmatore di Fuori; 15) Cala Moresca. 


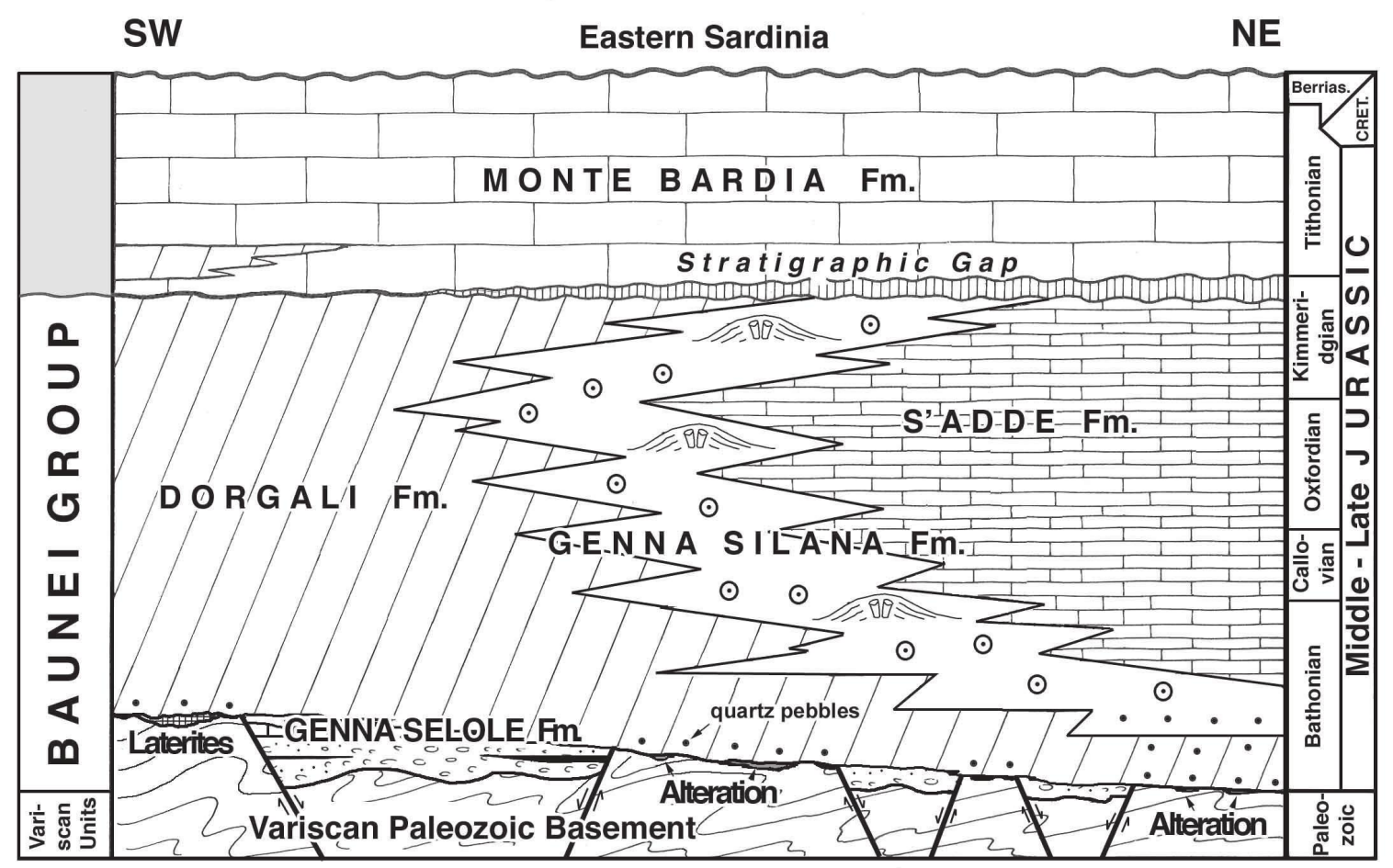

Fig. 2.- General stratigraphic scheme of the Middle-Late Jurassic Eastern Sardinia succession.

is a coarse, pebbly to sandy, deposit indicating fluvial high- to middle-energy braided alluvial fan environments, followed by 2) the Nurri-Escalaplano lithofacies, which is composed of finely-laminated sandstones, siltstones and clayey siltstones sedimented in low-energy coastal-palustrine-deltaic environments. Finally, the topmost lithofacies is 3 ) the Usassai-Perdadefogu lithofacies, which alternates carbonates and fine- to middle-grained siliciclastics locally with coal seams. This is typical of a deltaic-mixed lagoon environment ("coastal wetlands" sensu Suárez-González et al., 2015), and suggests the gradual passage to the carbonate shelf of the upper Dorgali Fm (Costamagna and Barca, 2004; Costamagna, 2013a, 2015) (Fig. 2). The Laconi-Gadoni and Nurri-Escalaplano lithofacies are partially coeval and so they interfinger.

The Genna Selole Fm locally starts with carbonates with scattered siliclastic pebbles that are related to the topmost Ussassai-Perdasdefogu lithofacies. The contact with the overlying carbonates of the Dorgali Fm has been placed where quartzarenites and lignite seams disappear (Costamagna and Barca, 2004). It is worth considering that Dieni et al. (2013) interpreted the Genna Selole Fm upper Ussassai-Perdasdefogu lithofacies sediment as the lower member of the Dorgali Fm ("Perda Liana Mb").

Jadoul et al. (2010), Lanfranchi et al. (2011) and Casellato et al. (2012) proposed a more detailed frame of the Middle to Late Jurassic carbonate stratigraphy of E Sardinia: that evidences the presence of ephemeral intraplatform basins during part of the Late Jurassic.

The marine carbonates of the Dorgali (Bathonian-Kimmeridgian), Genna Silana and S'Adde Fms (Callovian-Kimmeridgian) (Dieni and Massari, 1985a; Costamagna et al.,
2007) form a succession that is up to $600 \mathrm{~m}$ in the Supramonte - Monte Tuttavista area (Jadoul et al., 2010).

These deposits document a transgressive-regressive megacycle, and form the Baunei Group (Costamagna et al., 2007) (Fig. 2), which is a superunit linked to the sinking of the Tethys margin (Bathonian - Oxfordian) (Abbate et al., 1986; Bernoulli and Jenkyns, 1974). This latter was followed by a depositional regression (Oxfordian- Kimmeridgian) (Costamagna et al. 2007).

The Monte Bardia Fm (Tithonian-Berriasian) (Dieni and Massari, 1985a) is formed by a $400 \mathrm{~m}$ thick succession of peritidal carbonates, followed by a gap encompassing the Kimmeridgian and part of the Tithonian, possibly due to a sea level fall (Dieni and Massari, 1985a; Costamagna et al., 2007).

This Middle Jurassic - Early Cretaceous sedimentary cycle results from the Tethys opening in Sardinia (Costamagna et al., 2007). This succession is overlain by about $300 \mathrm{~m}$ of shallow-water carbonate deposits that are Late Cretaceous in age (Dieni and Massari, 1985a) followed by Tertiary siliciclastics and carbonates (Dieni and Massari, 1982; Zattin et al., 2008).

\section{New geological data: features of the Sardinia-Corsica Jurassic lower transgressive successions}

\subsection{Middle Jurassic Alpine Tethyan unconformity}

The erosive surface separating the Jurassic successions from the rocks underneath can be defined as an angular unconformity in central Sardinia and a non-conformity in the $\mathrm{NE}$ of the region. Nonetheless, usually it can be considered 

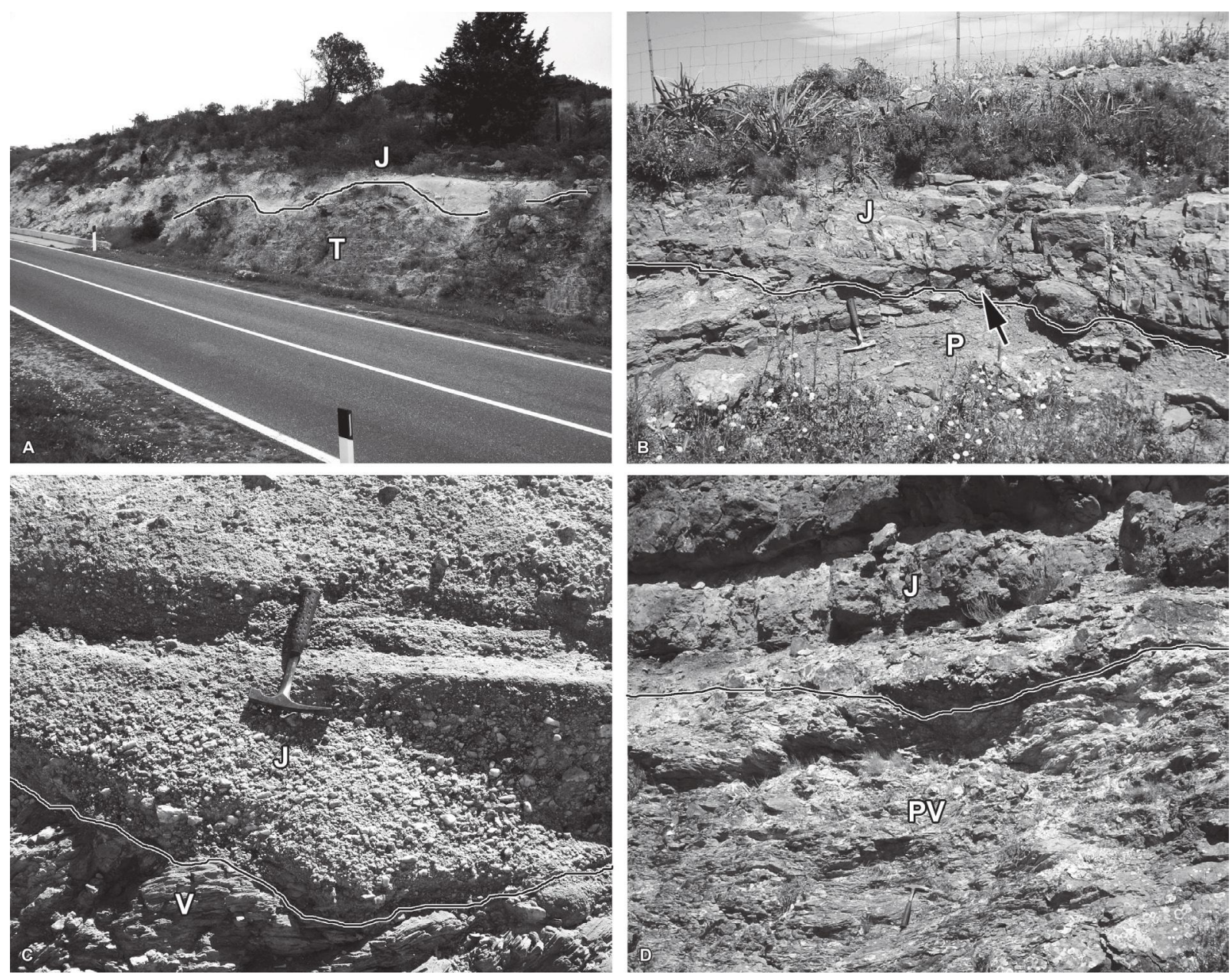

Fig. 3.- Different aspects of the Alpine Tethyan unconformity: A) Genna Selole Fm lower conglomerates resting unconformably on Triassic karstified dolostones; Orroli, SE Sardinia; B) Jurassic dolostones containing scattered quartz pebbles of the Dorgali Fm resting unconformably on well-stratified Permian blackish sandstones. At the base of the dolostones a darker Fe-rich level (arrow) is visible. Perdasdefogu, SE Sardinia. C) Genna Selole Fm lower conglomerates resting unconformably on the Variscan basement; Perdasdefogu, SE Sardinia. D) Carbonates and fine siliciclastics of the upper Genna Selole Fm resting unconformably on a laterized Variscan basement. Jerzu, SE Sardinia. Legend: V, Variscan basement; PV, laterized Variscan basement; P, Permian; T, Triassic; J, Jurassic.

an angular unconformity, and will therefore be described in this way in this paper.

The Middle Jurassic Alpine Tethyan angular unconformity (Fig. 3) frequently cuts the Variscan peneplain. Currently it can be observable as an irregular surface with very broad swales and narrow incised channels. Normal faults with decametric throw displace the entire peneplain (from the $\mathrm{S}$ to the $\mathrm{N}$ of the eastern part of the island along a distance of 180 $\mathrm{km}$ ): they subdivide it in smaller flat surfaces (Vardabasso, 1959) with very different elevations (300 to 900 a.s.l). Such faults can be interpreted as Variscan thrust faults (Barca and Costamagna, 1999) successively reactivated as normal faults.

In its southernmost outcrops, the unconformity truncates Triassic carbonate deposits that are strongly karstified. This paleosurface is locally coated by a dm-thick rusty crust that can be interpreted as an early paleosol that rests at the base of the Middle Jurassic Genna Selole Fm deposits.

In the SW area, the unconformity rests on top of different terrains, from Triassic to Variscan when crossing the NW/SE
Variscan SW-verging thrust belt. This latter is partially displaced by younger orthogonal faults and is formed by several sub-parallel tectonic compressive structures that superimpose the Meana Sardo tectonic unit over the Gerrei tectonic unit (Carmignani et al., 2001) (Fig. 4). Cinematic indicators (fault planes, tectoglyphs) and field geological evidence show that some of these lines, usually displaying a NW/SE trend, were reactivated along the same directions during the Middle Jurassic extensional Alpine tectonics (Fig. 4); in fact, these older Variscan tectonic lines cut the Triassic part of the Mesozoic cover. SW of the tectonic thrust belt, the Variscan basement is covered by Triassic deposits that are in turn blanketed by Middle Jurassic units. Conversely, to the NE, the Jurassic deposits directly rest on the Variscan basement. This suggests a regional normal fault belt of an age ranging between the Middle Triassic and Middle Jurassic, and a SW hanging wall (Fig. 4).

Further evidences of repeated reactivation of Variscan tectonic lines in Eastern Sardinia until Tertiary times were 
reported by Costamagna and Barca (1999) and Zattin et al. (2008).

Rarely, the unconformity may truncate the Permian siliciclastic to carbonate deposits and locally calcretized facies. These rocks initially deposited in basins created by post-Variscan (Permian) extensional tectonics (Fig. 5) (Cassinis et al., 2000 and references therein). In the end, the Permian molassic basins collapsed further into the Variscan metamorphic basement along reactivated Variscan NW/SE tectonic lines (Barca et al., 2001), which are often the same lines that later drove the Alpine extensional tectonics (Barca and Costamagna, 1999). Later they were levelled along with the enclosing Variscan metamorphic rocks. Accordingly, their upper surface ultimately became part of the Variscan peneplain (Fig. 5)

The Sardinia Variscan peneplain is locally blanketed by scattered patches of post-Variscan successions that are Carboniferous, Permian and Triassic in age. These successions can be formed by single Carboniferous, Permian or Triassic depositional cycles or alternatively superposed on each other. The patches represent the remains of larger covers that escaped erosion. Remnants of these successions are also fre- quently embedded as pebbles in the basal Middle Jurassic deposits (Fig. 6). The thickness of each of these sedimentary cycles may reach some hundreds of metres (Cassinis et al., 2000 and references therein). This evidences that the entire area underwent to intermittent sedimentation from the Late Carboniferous to the Middle Triassic, alternated with erosion episodes that were triggered by uplift phenomena (Cassinis et al., 2000; Carosi et al., 2005). Unconformable conglomeratic levels evidence erosion and the development of a levelled surface. These erosion-sedimentation processes affected the island on several occasions, and caused the development of repeated, superposed peneplains that were roughly parallel each other: with the last Middle Jurassic (Aalenian?) uplift (see below), they gave birth to the final surface to be covered by Middle Jurassic deposits, namely the Alpine unconformity.

The degree of weathering of the Variscan metamorphic basement at the unconformity ranges from a thin alteration "halo" to thick Fe-rich paleosoils, laterites and calcretes (developed after metamorphites), and the presence of loose sand (developed after granitoid rocks). By evaluating the alteration degree of the rocks located below the unconformity sur-

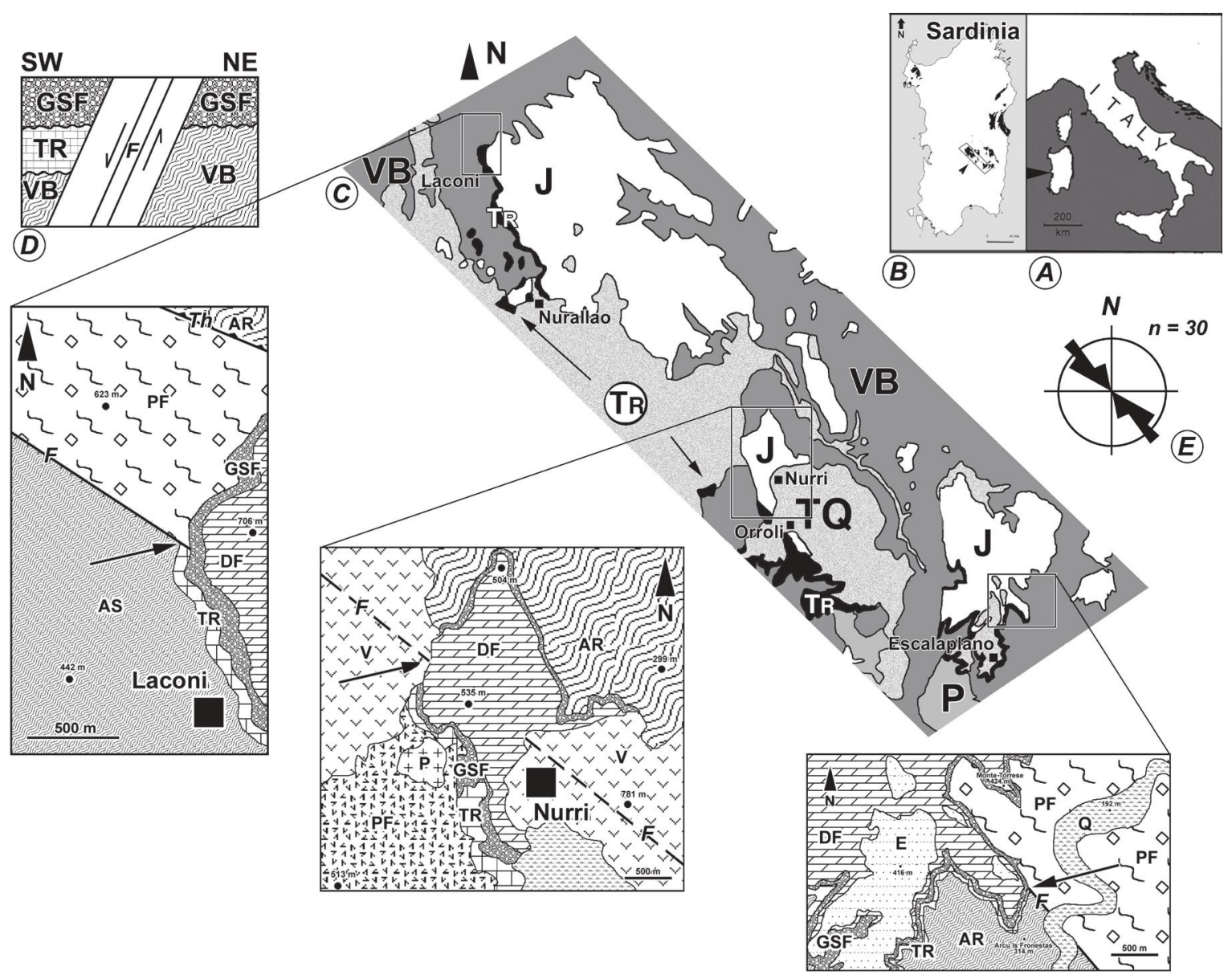

Fig. 4.- Geological map of the SE Sardinia reactivated thrust belt: A) Sardinia location; B) Thrust belt location (Jurassic outcrops evidenced in black); C) Geological map of the thrust belt area and detail insets; D) Geo-structural relationships of the stratigraphical units on the diverse sides of the structural lines; E) Rose diagram of the extensional structural lineaments in the Genna Selole Fm of Eastern Sardinia. Legend: AR: Ordovician Metasandstones; AS: Ordovician Argilloschists; DF: Dorgali Fm; GSF: Genna Selole Fm; E: Eocene deposits; Genna Selole Fm; J: Middle Jurassic deposits; P: Permian Volcanics; PF: Ordovician Metavolcanics; Q: Quaternary sediments; TQ: TertiaryQuaternary deposits; TR: Triassic deposits; V: Quaternary Volcanics; VB: Variscan basement; Th: Thrust; F: Fault. The arrows in the insets point to the main normal faults lowering the Triassic deposits. 


\section{Central Eastern Northern Eastern Sardinia Sardinia}

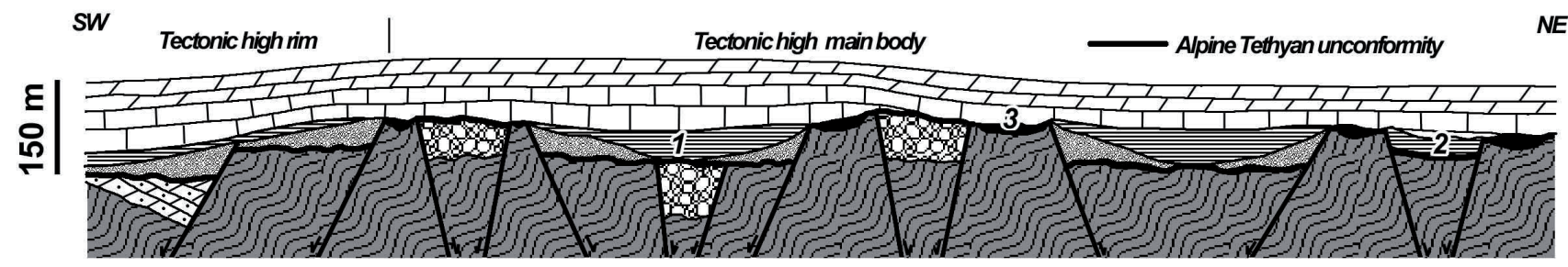

\begin{tabular}{|c|c|c|c|}
\hline & 808 & DIf & $\begin{array}{ll}\cdot i \cdot \\
\end{array}$ \\
\hline $\begin{array}{l}\text { Variscan } \\
\text { Basemer }\end{array}$ & $\begin{array}{l}\text { Permian } \\
\text { Molasse }\end{array}$ & Laterites & $\begin{array}{l}\text { Triassic } \\
\text { deposits }\end{array}$ \\
\hline
\end{tabular}
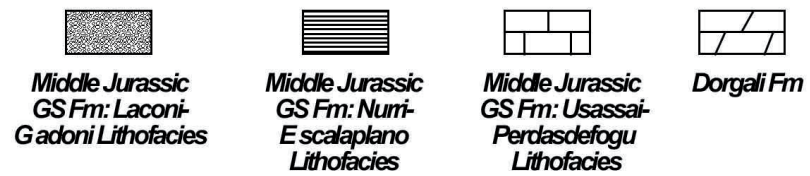

Fig. 5.- A SW/NE general sketch of the Eastern Sardinia high during Callovian with evidence of the small internal basin filled by Genna Selole Fm deposits. According with the decreasing width and depth of the internal basins we may have 1) basin filled by a complete Genna Selole Fm unit (the three lithofacies); 2) basin filled by an incomplete Genna Selole Fm (the conglomeratic facies is missing); 3) basin covered by only a remain of the Genna Selole Fm (all the siliciclastic units are missing and the basement is laterized). The vertical relief of the unconformity has been exaggerated.

face, it is possible to hypothesize the relative exposition time of the different sectors of the unconformity surface during the Middle Jurassic. As a consequence, the areas that have been longer exposed during Middle Jurassic emersion can be identified. In fact, these areas are marked by the same type of lateritic alteration, which is variable in grade, but not in kind, and is driven by a warm-humid climate (Rees et al., 2000). This is typical of Sardinia during this period (Scanu et al., 2014), and is thus unmistakable with respect to other emersion periods of different ages and showing diverse features: e.g., the Permian emersion periods are never marked by pedogenetic processes. The laterized areas should be the ones that suffered the longest period of exposition. Furthermore, no evidence of reworking or transport of the paleosoils has been found, so they are considered to be an "in situ" manifestation of an early Middle Jurassic weathering process.

Levelled areas of long-lasting exposition have been identified and precisely delimited in this way. They are mainly located in SE Sardinia. Some smaller areas have also been evidenced in the NE of the island. Nonetheless, such areas are gradually reduced towards the North, disappearing almost completely in the northwesternmost areas: they are replaced by basically unaltered rocks below the Middle Jurassic deposits.

\subsection{Facies and areal variations of the transgressive Genna Selole Fm}

The Genna Selole Fm (Bajocian-Bathonian to Bathonian: Del Rio, 1976, 1984; Dieni et al., 1983) are mainly developed in the southernmost outcrops of the Middle Jurassic succession: northwards, it thins out irregularly and tends to disappear, as the Middle Jurassic succession may start directly with the carbonates of the Dorgali Fm.
Below are briefly described some representative stratigraphic sections of the Genna Selole Fm from the SE to the $\mathrm{NE}$ of the island along a distance of nearly $170 \mathrm{~km}$ (Fig. 1). These sections illustrate the general evolution of the unit northwards (Fig. 7).

1) Pitzu Rubiu quarry (Nurallao) (Figs. 1, 7) - At Pitzu Rubiu (Nurallao), the Genna Selole Fm rests unconformably over the Middle Triassic Monte Maiore Fm carbonates (Costamagna and Barca, 2002). It is formed by thick alternations of quartzose conglomerates and subordinated quartzarenites, passing in the upper ten metres of the section to dark pelites. The disappearance of the terrigenous content marks the passage to the dolostones of the Dorgali Fm. The total thickness of the Genna Selole Fm in the section is $57 \mathrm{~m}$.

2) S'Arcu de Is Fronestas (Escalaplano) (Figs. 1, 7) - Here, the Genna Selole Fm rests unconformably on the siliciclastic Middle Triassic Escalaplano Fm (Costamagna et al., 2000). The Genna Selole Fm starts with alternations of quartzose conglomerates and coarse sandstone lenses passing upwards into alternations of sandstones and grey pelites. Further upwards, the appearance of carbonates predates the passage to the dolostones of the Dorgali Fm. In this section is remarkable the presence in the lower conglomerates of scattered pebbles of Permian silificied limestones. The total thickness of the unit is $20 \mathrm{~m}$.

3) S'Arcu sa Perdia (Tertenia) (Figs. 1, 7) - Here, a thin Genna Selole Fm made of alternations of breccias, clayey siltites and carbonates rests unconformably on a strongly weathered Variscan basement impregnated with Fe oxides (due to the percolation of a now dismantled lateritic paleosoil: Vacca, pers. comm.). The unit passes upwards to the Dorgali Fm. The total thickness of the Genna Selole Fm is $3.70 \mathrm{~m}$.

4) Bruncu Matzeu (Osini) (Figs. 1, 7) - Quartzose conglomerates and sandstones rest unconformably over the unal- 

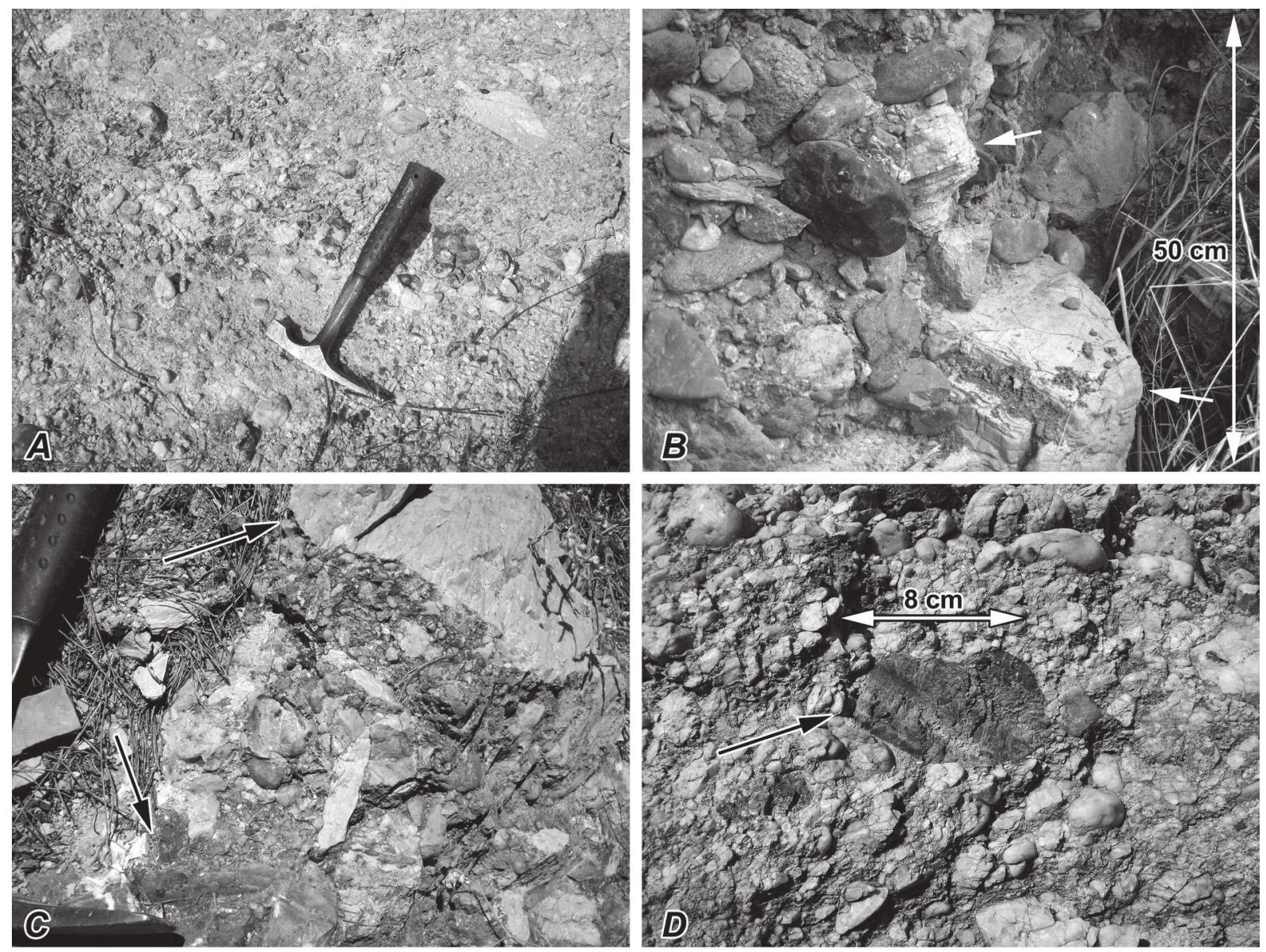

Fig. 6.- Polygenic conglomerates of the lower Genna Selole Fm. Besides the quartz, clasts that can be found are: A) Triassic carbonates and Variscan metamorphics, SE Sardinia; B) Triassic carbonates (arrow): central Sardinia; C) Triassic (?) carbonates (arrow): NE Sardinia; D: Permian silicified carbonates: SE Sardinia.

tered Variscan basement. Upwards, they pass into dark grey to blackish siltites with rare thin beds of grey sandstones. These latter are alternations of limestones and blackish siltitic clays before passage to the Dorgali Fm dolostones. The total thickness of the unit is $21 \mathrm{~m}$.

5) Monte Oro (Baunei) (Figs. 1, 7) - Thin grey clayey siltites containing scattered pebbles of quartz rest unconformably over a strongly weathered and laterized basement at Monte Oro. These siltites are followed by thick-bedded calcareous dolostones containing rare quartz pebbles. The dolostones of the Dorgali Fm follow. The total thickness of the Genna Selole Fm is nearly $3.50 \mathrm{~m}$.

6) Dispensa Selole (Baunei) (Figs. 1, 7) - Over the weathered granitoid batholith lie down first polygenic conglomerates and minor sandstone bodies; they locally contain some pebbles of Triassic dolostones. They are followed by alternations of fine sandstones and blackish plant-rich pelites preceding alternations of fine sandstones and pelites, passing to well-stratified alternations of carbonates, marls and pelites. The dolomitic Dorgali Fm follows. The total thickness of the Genna Selole Fm here is $49 \mathrm{~m}$.

7) Punta Orotecannas (Urzulei) (Figs. 1, 7) - Quartzose conglomerates and rare sandstones followed by alternations of sandstones and blackish pelites rest over the weathered Fe-rich Variscan basement at Punta Orotecannas: they pass to limestones with rare intercalations of sandstones and blackish siltites, which in turn are covered by the dolostones of the Dorgali Fm. The total thickness of the Genna Selole Fm here is $9-10 \mathrm{~m}$.

8) Gologone (Oliena) (Figs. 1, 7) - Here, the Genna Selole Fm rests over the weathered Variscan basement and consists of polygenic (Triassic-Early Jurassic? carbonates, Permian volcanics, Permian silicified carbonates) to quartzose conglomerates followed first by alternations of sandstones and blackish siltites and finally by alternations of limestones and blackish sandstones and siltites. The total thickness of the unit here is $10 \mathrm{~m}$.

9) Monte Tuttavista (Orosei) (Figs. 1, 7) - Here, a weaklyweathered basement is unconformably covered by a carbonate-rich quartz conglomerate followed by quartzose pebbly carbonates. These rocks rapidly pass upwards into the dolostones of the Dorgali Fm. The thickness of the Genna Selole Fm here is about $3 \mathrm{~m}$.

10) Su Ercone (M. Albo, Lula) (Figs. 1, 7) - Conglomerates and rare sandstones rest unconformably over the unaltered Variscan basement. They are followed by alternations of 


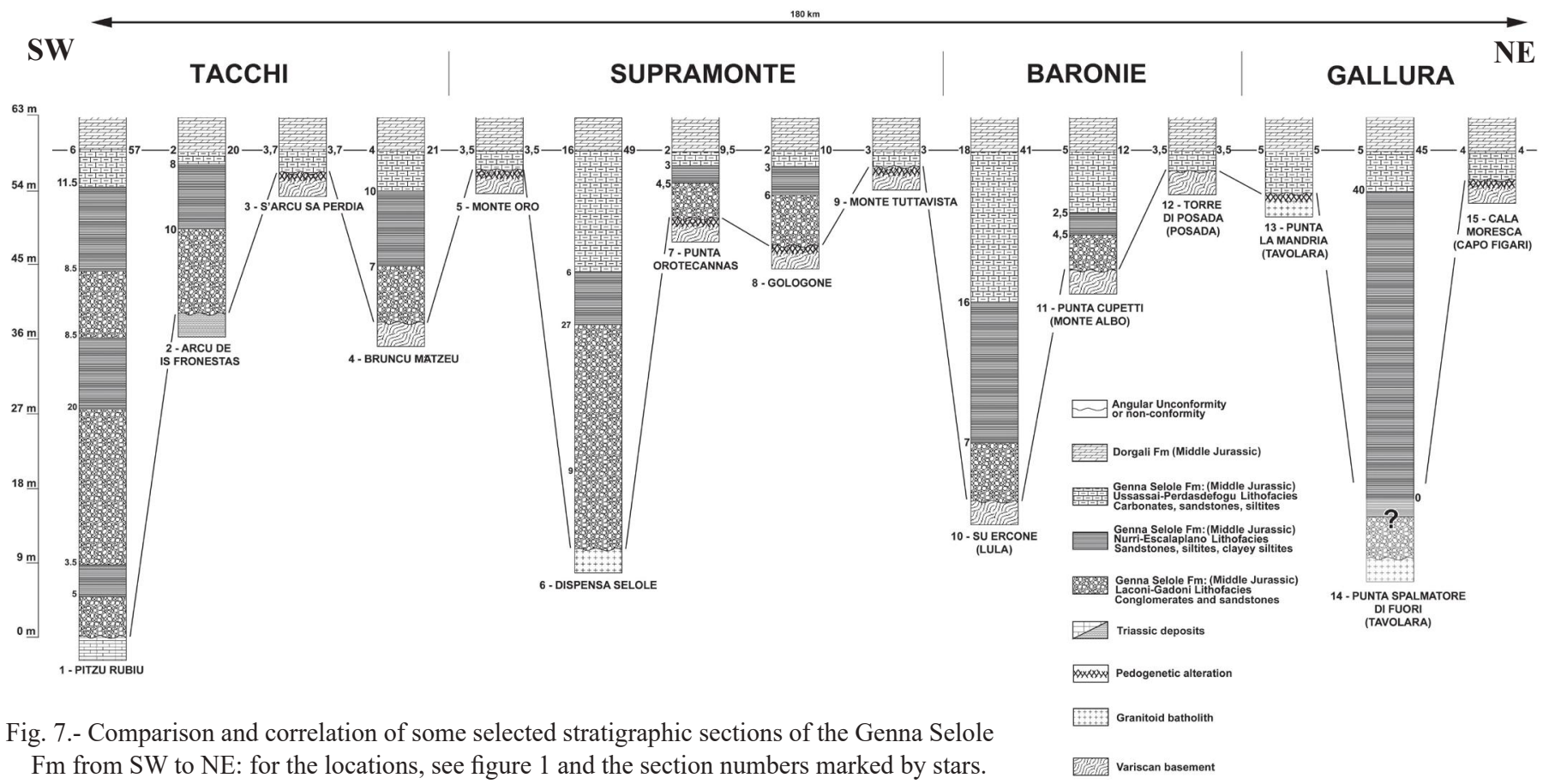

quartzarenites/quartzsiltites and blackish siltites. They are in turn covered by alternations of quartzarenites, quartzose dolomites and limestones with rare, thin blackish pelites. These lithologies pass upwards into the dolomitic beds of the Dorgali Fm. The thickness of the Genna Selole Fm here is $41 \mathrm{~m}$.

11) Punta Cupetti (M. Albo) (Figs. 1, 7) - Polygenic fine conglomerates rest unconformably over an unaltered blackish Variscan basement. They are followed by blackish siltites, and are covered by $5 \mathrm{~m}$ of alternations of quartzarenitic dolostones, dolostones and rare quartzarenitic beds. The dolostones of the Dorgali Fm appear with the disappearance of the siliciclastic content. The total thickness of the Genna Selole Fm here is about $12 \mathrm{~m}$.

12) Torre di Posada (Posada) (Figs. 1, 7) - Here dolostones rich in quartz pebbles rest over an unaltered Variscan base- ment. These deposits represent the topmost Genna Selole Fm lithofacies before passage to the dolostones of the Dorgali Fm. The thickness of the Genna Selole Fm here is $3.5 \mathrm{~m}$.

13) Punta La Mandria (Tavolara SW) (Figs. 1, 7) - The weathered, arenized granitoid basement is sharply covered by dolostones rich in quartz grains representing the topmost facies of the Genna Selole Fm followed upward by the pure dolostones of the Dorgali Fm. The thickness of the Genna Selole Fm is $5 \mathrm{~m}$.

14) Punta Spalmatore di Fuori (Tavolara NE) (Figs. 1, 7) - From the coastline are found quartzarenites with limited intercalations of blackish, locally lignitiferous clayey siltites, followed by alternations of siltitic clays and marls. They are covered by alternations of dolostones and marls. The end of the marls indicates the passage to the Dorgali Fm. The total
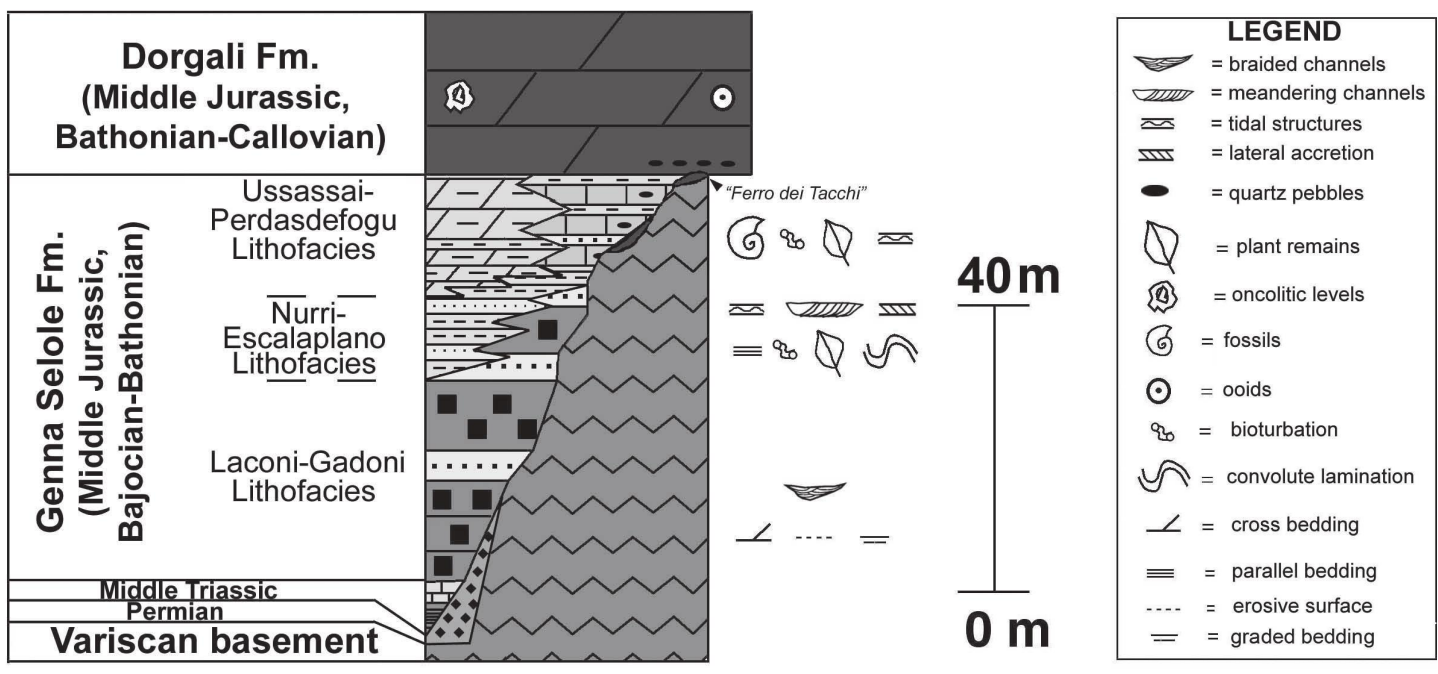

Fig. 8.- Stratigraphy of the Genna Selole Fm. 


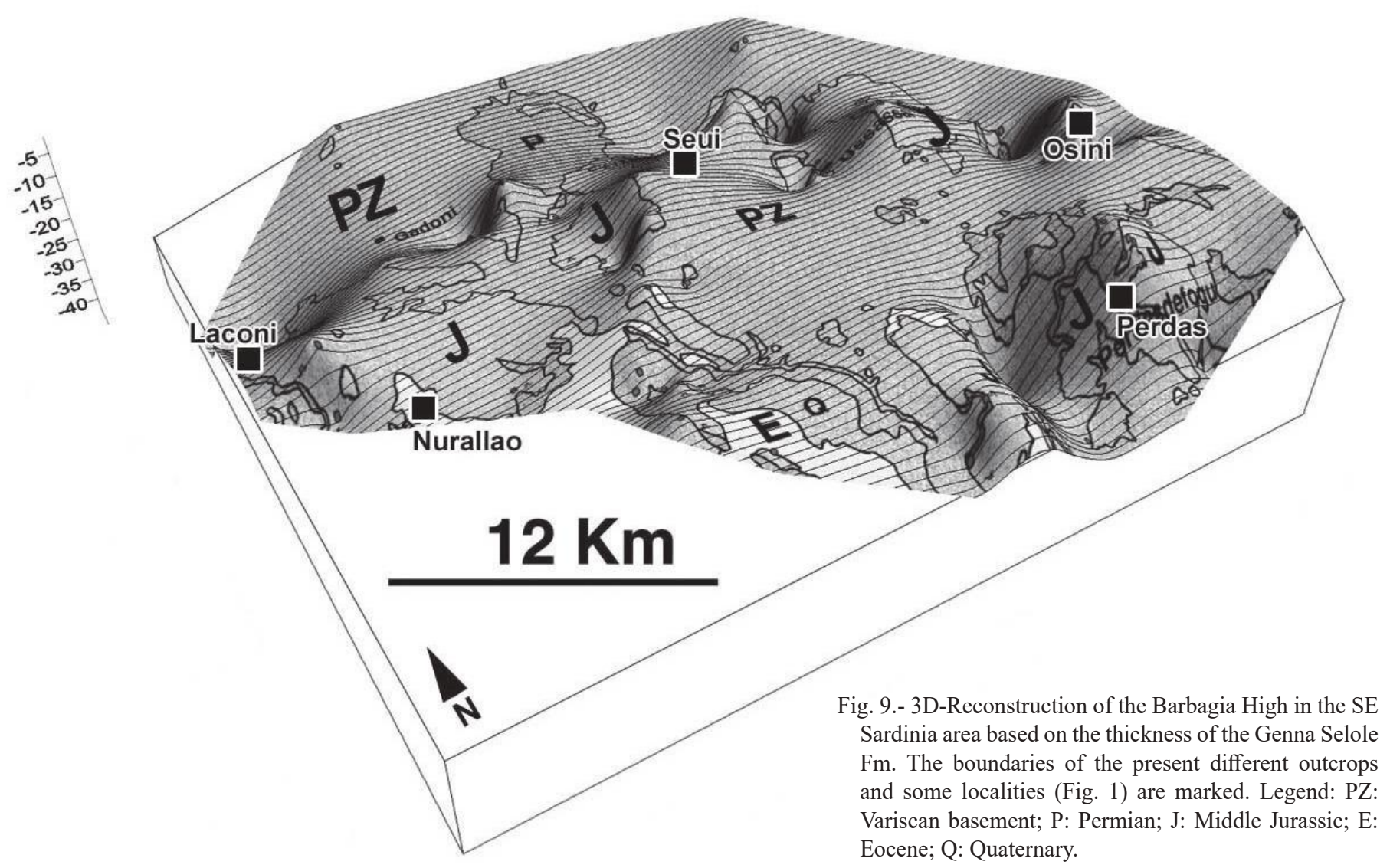

thickness of the unit here is at least $40 \mathrm{~m}$. Given the likely presence of conglomerates below sea level, the section could be significantly thicker.

15) Cala Moresca (Capo Figari) (Figs. 1, 7) - Here, pebbly sandstones alternating with dolomitic beds containing small quartz pebbles rest over the weakly-weathered Variscan basement. The disappearance of the sandstone beds and the quartz content indicates passage to the Dorgali Fm dolostones. The thickness of the Genna Selole Fm here is $4 \mathrm{~m}$.

Relying on previously revealed data, along with the irregular northwards thinning trend, the Genna Selole Fm shows a clear mean fining-upwards trend, as well as a transgressive trend. The related depositional environments are, from the base: continental braided fluvial fans interfingered in the upper part with transitional mixed coastal-palustrine-deltaic contexts; and carbonate lagoons / shoals (Costamagna, 2013a, 2015). The fining-upwards succession and the evolving sedimentary environments have been also interpreted as an evidence for the polyphase peneplanation of the mainland of Sardinia. The different lithofacies of the Genna Selole Fm may not all be present in a given stratigraphic section: they have complex lateral, interfingering relationships (Fig. 8) due to laterally-changing environmental conditions that are related to the gradually-reducing altitude gap with respect to the bottom and the shoulders of any swell located on the peneplane, the variable discharge of the waterways, and the distance from the coastline and the sediment source. As shown by the stratigraphic sections described, the Genna
Selole Fm is thicker $(80 \mathrm{~m})$ in the southernmost areas (Dieni et al., 2013). Accurate comparisons between the stratigraphic sections allow us to point out the extreme variability of the sedimentary features (compositional and textural maturity, grain size) and thickness of the unit over short distances; in some cases, we are able to draw the main features and profile of the buried substrate (Fig. 9). This unit thins out northwards, as the coarse-grained lithofacies disappear. While in the SE area, the Genna Selole Fm typically has a significant thickness and lateral persistence (Fig. 7), moving northwards it is usually characterized by a few metres of laterally discontinuous, quartz-rich impure carbonates that are locally affected by paleokarstic features (Costamagna, 2015) belonging to the topmost, mainly calcareous, facies. The lower, coarser siliciclastics are only found in small pockets and swales representing morphological irregularities of the transgressed basement surface. In some scattered NE areas the siliciclastic coarsegrained facies thickens again significantly, reaching nearly 30 m (Fig. 7).

Pebble imbrications in the lower conglomerates give paleocurrents of the debris (Fig. 10). Usually, they have a radial distribution from some definite points, thus marking particular areas of erosion, as the emerged tectonic highs, and the provenance of the debris.

To summarize, the base of the Genna Selole Fm overlying the unconformity can be either coarse- or fine-grained. The substrate is generally unaltered where overlain by con- 

tions inferred from imGenna Selole Fm from the border of the black areas that are the Jurassic outcrops: every arrow represents at least four measurements.
Fig. 10.- Paleocurrent direcbrication structures in the conglomerates of the lower

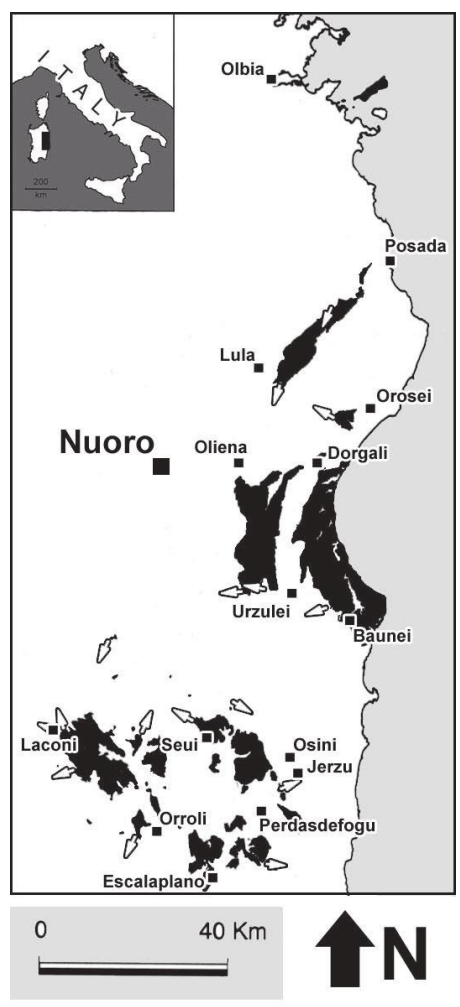

glomerates, while a laterite is locally found underlying finegrained siliciclastics or carbonates.

Based on biostratigraphic data from the lowest bed lying over the unconformity, the age of the unconformity itself gradually becomes slightly younger southwards (starting from NE Sardinia, there are early Bathonian fossils in ma- rine deposits - Dieni and Massari, 1985b - of the UsassaiPerdasdefogu lithofacies of the Genna Selole Fm directly laying over the Variscan basement; ending in SE Sardinia, where the Bajocian-Bathonian plant remains - Del Rio, 1976, 1984 - in the intermediate palustrine deposits of the NurriEscalaplano lithofacies of the Genna Selole Fm are located at least $30 \mathrm{~m}$ above the unconformity). Moreover, Dieni et al. (1983) proposed the heterochronicity of the Genna Selole Fm transgression over the older rocks. If compared with the successions of the SE part of the island, the precocity and speed of the transgression that is related to the collapse of the Variscan basement in this $\mathrm{N}$ area is also suggested here by the rapid passage from the shallow deposits of the Dorgali Fm to the middle to the outer ramp limestones with the hard ground of the S'Adde Fm (Fig. 1) (Costamagna et al., 2007; Casellato et al., 2012); in fact, the inner ramp of the Dorgali Fm is much thinner in these northern areas.

\subsection{Synsedimentary tectonics}

Evidence of synsedimentary tectonics occurs in the entire Genna Selole Fm: they are frequent in the SE area of the island where the unit is the thicker. They are synsedimentary faults (Figs. 11a, b, c, 12), convolute laminations related to seismic shocks (Fig. 11d), slumps (Fig. 11e), neptunian dykes, brecciated carbonate levels.

Furthermore, evidence of pre-Middle Jurassic tectonics is also visible on a larger scale: e.g. at Perdasdefogu in the SE area (Fig. 13), the Jurassic succession sutures Permian (Triassic?) faults. Often, synsedimentary faults penetrate from the
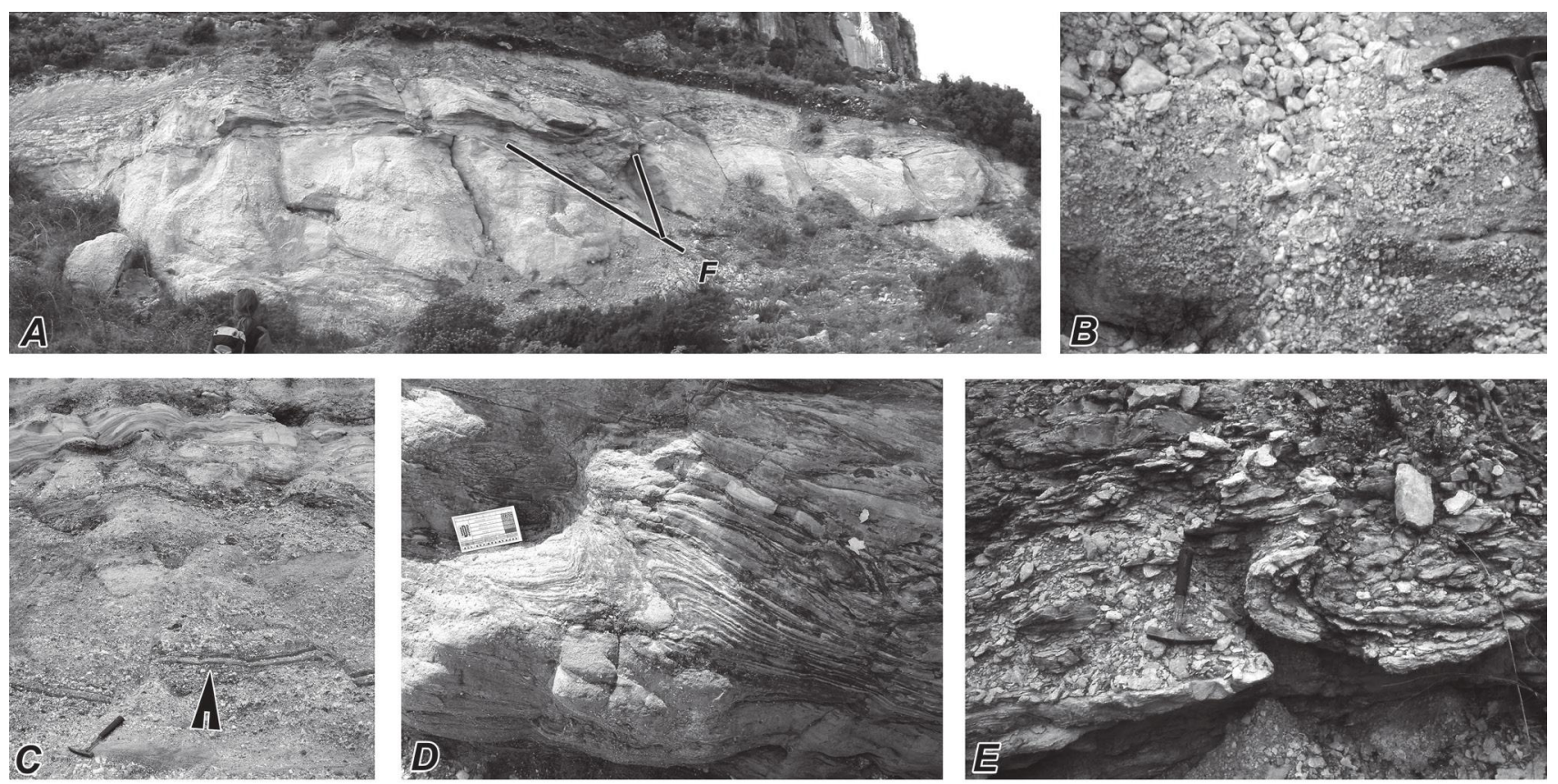

Fig. 11.- Synsedimentary features in the Genna Selole Fm: A) Sinsedimentary faults (F) in conglomerates sealed by undisturbed sandstone beds. Laconi-Gadoni Lithofacies, SE Sardinia. B) Synsedimentary fracture filled by conglomerates. Laconi-Gadoni Lithofacies, SE Sardinia. C) Lignitiferous levels in conglomerates (arrow) dislocated by extensional features: they are located below undisturbed sandstone beds. LaconiGadoni Lithofacies, SE Sardinia. D) Convolute laminations cut by a little reverse fault in siltites and sandstones. Nurri-Escalaplano Lithofacies, SE Sardinia. E) Slumping in the fine Nurri-Escalaplano Lithofacies deposits, SE Sardinia. 


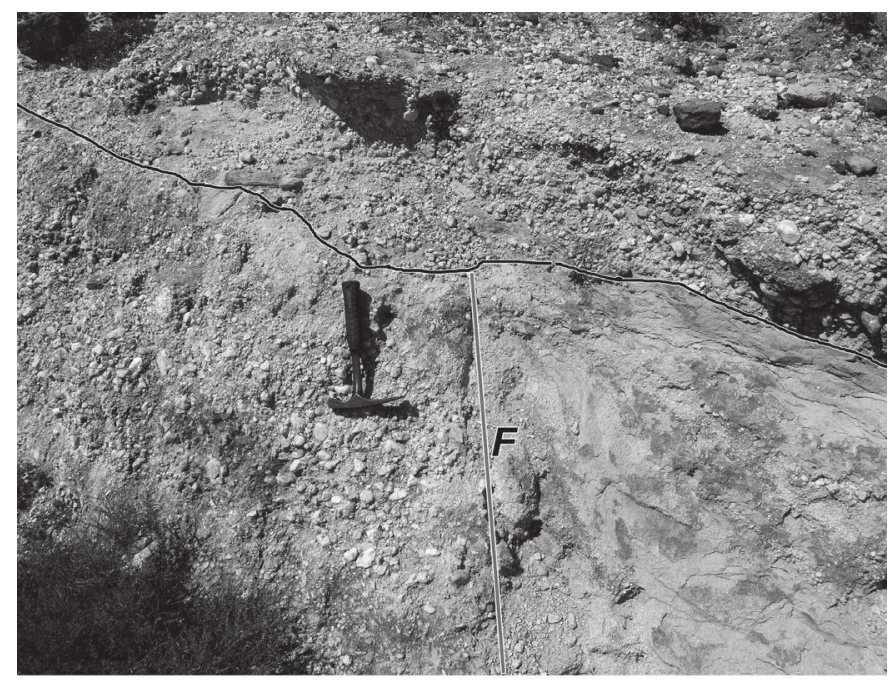

Fig. 12.- Sinsedimentary fault in the Laconi-Gadoni Lithofacies of the Genna Selole Fm (SE Sardinia).

lower basement and continue upwards into the upper Middle Jurassic sedimentary cover, partially displacing it. Consequently, the vertical and lateral frequency of these structures evidence extensional tectonics throughout the time of deposition of the Genna Selole Fm. The measured synsedimentary faults, fractures and dykes have a NW/SE attitude (varying from $\mathrm{N} 130^{\circ}$ to $\mathrm{N} 150^{\circ}$ : Fig. 4e). They have identical direction as the former compressive Variscan tectonic lines and shows their reactivation in Mesozoic times. These structures are interpreted as pointing to strong earthquakes. Rodríguez Pascua et al. (2000, Fig. 13) identified in a Late Miocene lacustrine sequence of the Betic cordillera several types of deformational structures that they interpreted as seismites. They classified and ranked such structures in order to use them to rate the earthquakes intensity. So, using their visual standards (Rodríguez-Pascua et al., 2000, Fig. 13), the structures described above in the Genna Selole Fm may possibly be rated as earthquakes up to a magnitude of six. Synsedimentary extensional structures are still present in the upper carbonate units of the Middle Jurassic succession, although they tend to decrease in frequency and intensity upwards, suggesting a gradual waning of the tectonic activity. Nonetheless, evidence of synsedimentary tectonics persists up into the $\mathrm{M}$. Bardia Fm (Jadoul et al., 2010).

\subsection{Petrography of the Genna Selole Fm}

The petrographic analysis of the terrigenous part of the Genna Selole Fm is based on 40 thin sections of sandstones, using the Gazzi-Dickinson point-counting method (Gazzi, 1979; Dickinson, 1970). A minimum of 300 framework grains were identified and counted per sample at a spacing of $0.5 \mathrm{~mm}$. This method provided information about the composition of the unit and the provenance of the sediments. The composition commonly and gradually changes upwards, and may change with the thickness of the unit and the nature of the substratum. The unit typically displays increasing textural maturity (as polygenic conglomerates and litharenitic/arkosic sandstones change to monogenic quartzose conglomerates and quartzarenites). Sometimes, a mature quartzose succession is developed from the base to the top of the siliciclastic lithofacies of the Genna Selole Fm.

Usually, the conglomerates are clast-supported and have pebbles and cobbles that are up to $30 \mathrm{~cm}$ wide. They are predominantly monogenic and formed by monocrystalline to polycrystalline strained quartz. Rounded quartz pebbles are often broken, suggesting that they may be derived from the reworking of older sedimentary cycles Late Variscan to Triassic that previously covered the ancient Variscan peneplain. In the SE areas, where the Jurassic succession rests on lowgrade metamorphic units, the quartz is usually monocrystalline and derived from the erosion of hydrothermal veins cutting the basement (Fig.14a). Northwards, as the metamorphic grade of the basement increases, the monocrystalline quartz is gradually replaced by polycrystalline strained undulose metamorphic quartz (Fig. 14c, d); in the central areas, the percentage of this latter quartz type is about $50 \%$, while in the northern territories the polycrystalline quartz is virtually exclusive. Locally, where the Genna Selole Fm lies on Permian igneous or sedimentary rocks, the basal conglomerate may only be formed by pebbles of the porphyric granitoids or silicified carbonates.

The conglomerates are rarely polygenic; in this case they are formed by pebbles coming from all the rocks found below the Alpine Tethyan unconformity (quartz, Variscan metamorphics of various grades, lydites, granites, porphyric granites, Permian silicified carbonates, Triassic carbonates). The distribution of the polygenic conglomerates is peculiar:

SE PERDASDEFOGU TACCO PERDA MURA

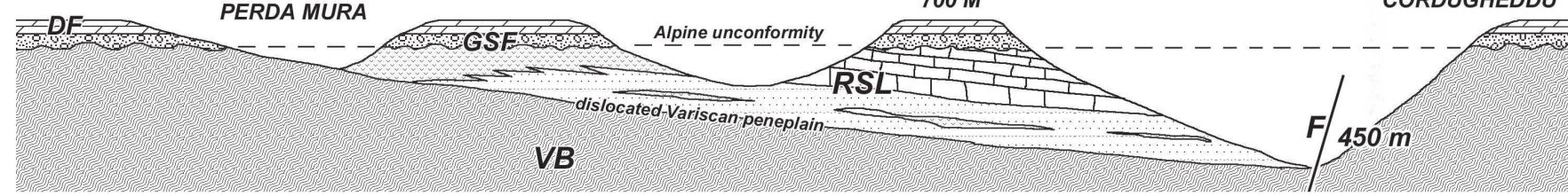

Fig. 13.- Simplified geological section of the Perdasdefogu Tacco (SE Sardinia): the presence of a post-Permian, pre-Middle Jurassic fault is marked by the NW-ward increase of thickness of the Permian succession. Legend: VB: Variscan basement; RSL: Rio Su Luda Fm (Early Permian); GSF: Genna Selole Fm; DF: Dorgali Fm; F: Fault. 

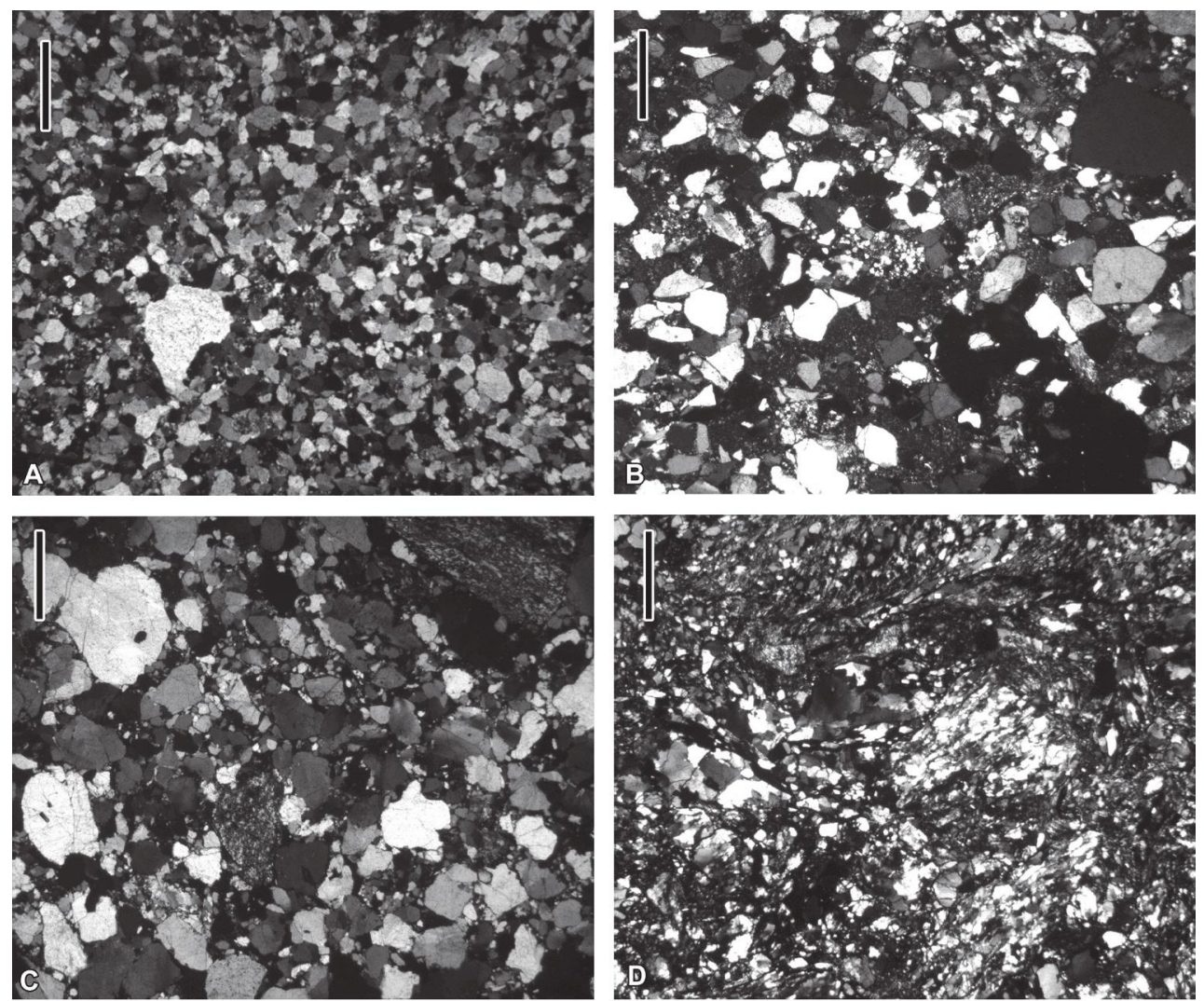

Fig. 14.- Petrographic micrographs of the Genna Selole Fm siliciclastics: A) Quartzarenite, SE Sardinia, 1.25, Nx; B) Litharenite with schists fragments and minor polycristalline quartz, SE Sardinia, 1.25, Nx; C) Litharenite with prevalent polycristalline quartz, NE Sardinia, 1.25, $\mathrm{Nx}$; D) Litharenite (high-rank phyllarenite) with polycristalline quartz and micaschists fragments, NE Sardinia,1.25, Nx. Scale $1 \mathrm{~mm}$.

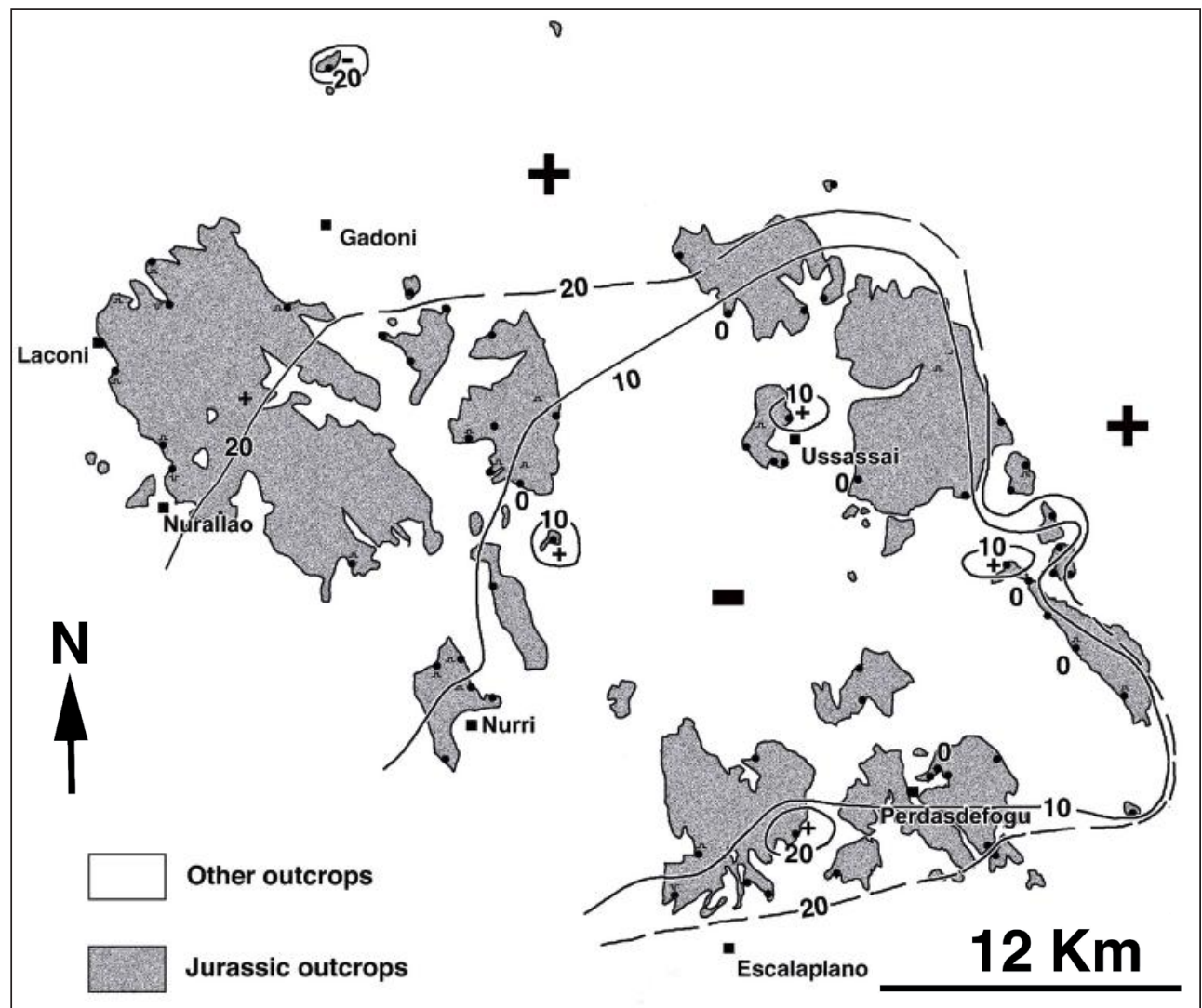

Fig. 15.- Isopachs of the Genna Selole Fm in SE Sardinia. The locations where the Formation is absent are indicated by a zero isopach. Black dots define the location of the described stratigraphic sections. 


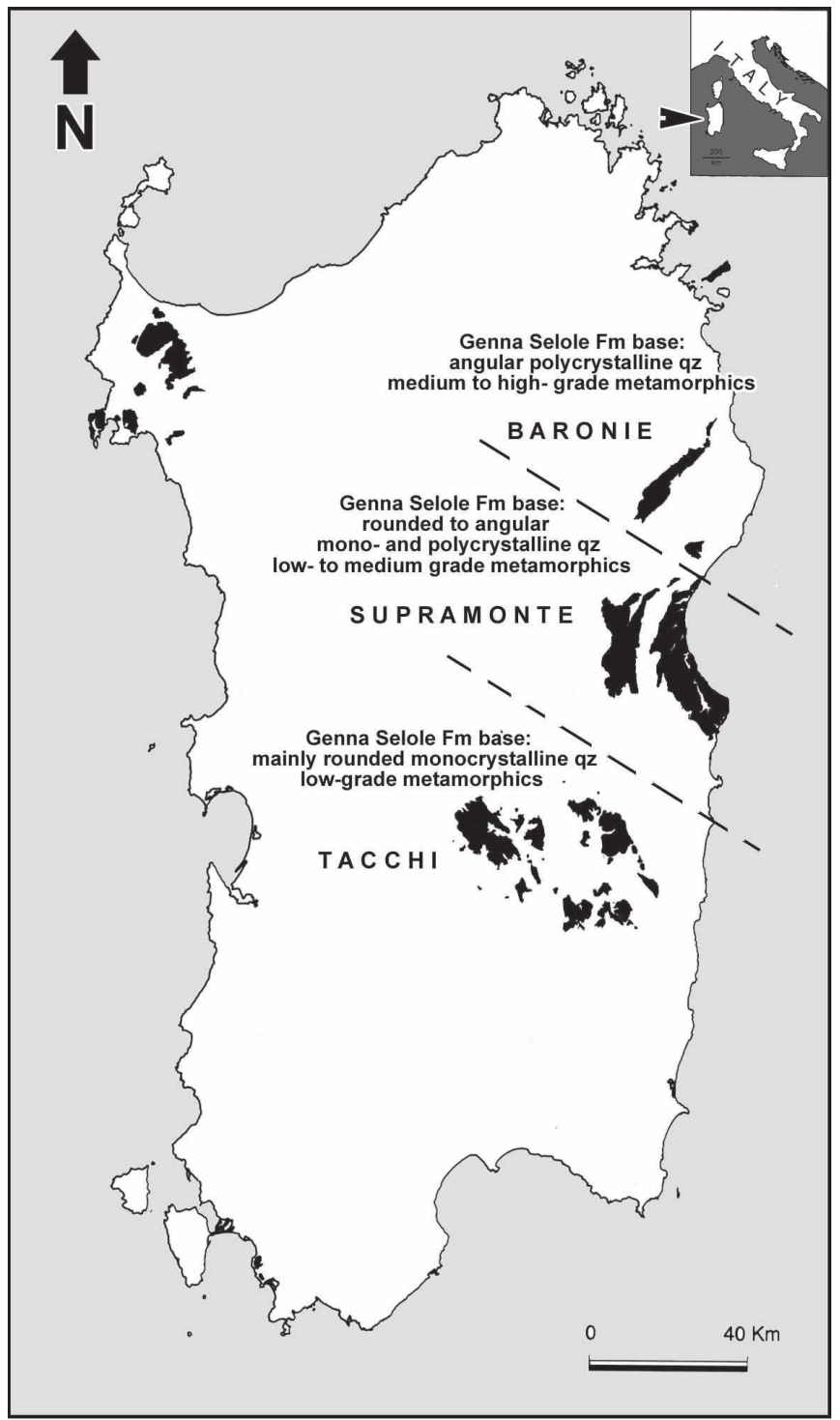

Fig. 16.- Composition of the Genna Selole Fm base in the diverse areas of Eastern Sardinia. Jurassic outcrops in black. their outcrops, located at the base of the Genna Selole Fm, evidence and surround circular areas where the Genna Selole Fm instead starts directly over the basement with finer deposits like sandstones and pelites, or even quartz-rich carbonates (Fig. 15). The nature of the metamorphic rock pebbles is variable: in the SE areas, where the Tethyan unconformity truncates terrains of a lower metamorphic grade, they consist of slates and metavolcanics (Fig. 14b). Moving northwards, with the increasing metamorphic grade of the basement, pebbles of schists appear. Finally, in the northernmost areas, the metamorphic rock pebbles are micaschists and gneisses (Figs. 14d, 16).

The clasts are usually rounded to sub-rounded, but angular quartz pebbles (breccias and conglomerates/breccias) may form intercalations or even complete stratigraphic sections. The breccias are more common towards the N, parallel with the textural immaturity of the conglomerates. The pebbles apparently also document formations that are no longer preserved, e.g. Triassic carbonate pebbles at the base of the unit in central Sardinia, which suggest that a Triassic cover previously existed across the area.

The monogenic conglomerates generally have a low content of a sandy quartzose matrix. Conversely, the polygenic conglomerates have a caolinite matrix which documents the weathering of metavolcanic clasts (Marini et al., 1991).

In thinner successions, the basal conglomerates are replaced by pebbly sandstones, generally quartzarenites, while subarkoses are subordinate. Quartzarenites dominate in the SE areas, while sublitharenites and subarkoses become dominant northwards, parallel to the thinning of the Genna Selole Fm. The components are, in a decreasing order of frequency, quartz, k-feldspar, rock fragments, rare biotite and muscovite. The quartz grains are prevalently monocrystalline in the $\mathrm{SE}$ areas, and polycrystallyne with irregular boundaries northwards (Figs. 16, 17). A significant post-depositional
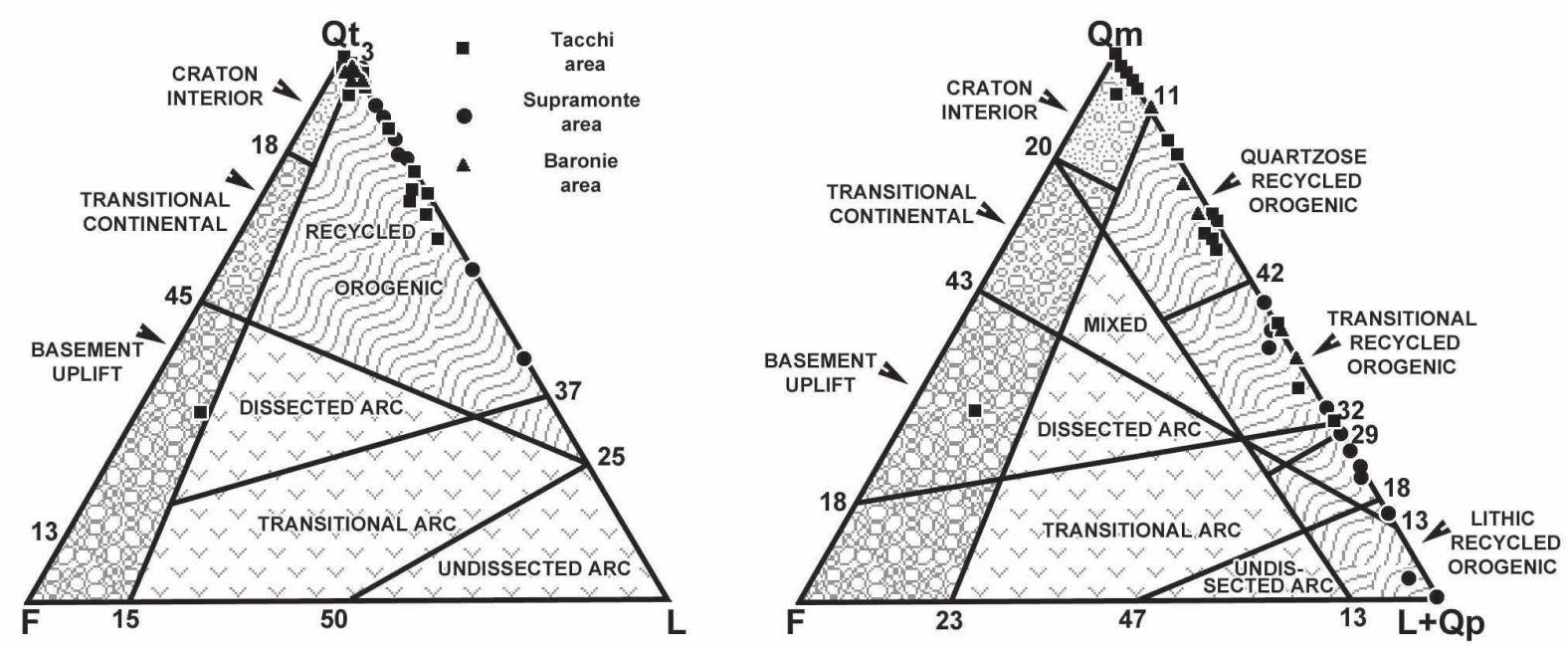

Fig. 17.- QFL and QmFLt plots for framework modes of the siliciclastic part of the Genna Selole Fm: discriminating fields after Dickinson et al. (1983). 


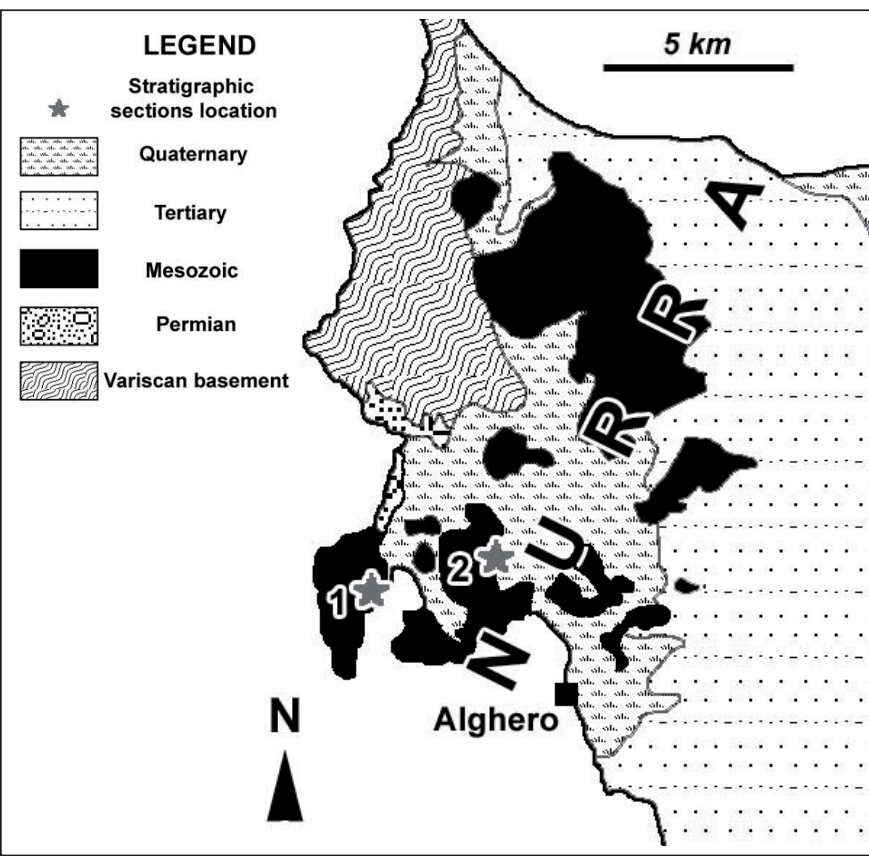

Fig. 18.- Geological sketch of NW Sardinia (geological framing in Fig. 1A, 2). Stratigraphic sections: 1) Alghero-Capo Caccia road; 2) Monte Vaccargiu quarry.

compaction of the sandstones is evidenced by their tight grain packing. Locally pressure-solution structures are visible.

The carbonates (topmost Ussassai-Perdasdefogu lithofacies) of the Genna Selole Fm show a decreasing terrigenous content upwards. Sometimes, a significant terrigenous input may restart ephemerally, as seen in metre-thick beds located above the last terrigenous intercalations of the Genna Selole $\mathrm{Fm}$, forming carbonate conglomerates or pebbly carbonates embedded in the dolostones of the Dorgali Fm.

\subsection{Western Sardinia}

In W Sardinia (Fig. 18), a carbonate platform succession was deposited during the Jurassic period (Cherchi and Schroeder, 1986a; D'Argenio et al., 1986; Jadoul et al., 2010). This platform was characterized by shallow bioclastic lagoonal to ooidal marginal marine environments with limited, cyclical shifts of the shoreline, possibly due to eustatic causes. In the early Middle Jurassic (Aalenian - Bajocian), ephemeral coastal to paralic, brackish to freshwater, environments developed: they consists of well-bedded marly to clayey deposits rich in charophytes, lacustrine ostracods and microflora (Ashraf et al., 1984). These deposits locally have a mud-cracked cap. Here Cherchi and Schroeder (1986b) described a Bajocian-Bathonian succession that was $15 \mathrm{~m}$ thick and formed by alternations of mudstones and algal laminites, calcarenites, and clayey and silty levels.

This succession can be interpreted as largely marine in nature, with punctuated episodes of marginal marine to lacustrine sedimentation and subaerial exposure during Aalenian to Bajocian times. The analysis of the diverse microfloristic assemblages suggests inter- to supratidal environments, palustrine zones and even dryer environments (Del Rio, 1990), implying vicinity to an emerged land.

\subsection{Corsica}

In Variscan Corsica, the presence of autochtonous Mesozoic successions similar to those in Sardinia is proved by isolated outcrops as the Chiappa conglomerates and the Punta Calcina succession in the $\mathrm{S}$ of the island (Fig. 19).

The analysis of the pebbles contained in the Eocene Chiappa conglomerates allowed to reconstruct a Mesozoic succession with a clear W Sardinia affinity ("Sardo-Provencal domain") (Durand Delga and Peybernés, 1986). As a consequence, their provenance from a presently-eroded Corsica Mesozoic cover is suggested.

At Punta Calcina (S Corsica), a Variscan basement is unconformably covered by a Jurassic succession (Peybernés et al., 2000) ("Extra-Alpine Domain", Durand Delga and Peybernés, 1986). This succession starts with thin siliciclastic alternations of quartzose-micaceous sandstones and subordinate lignitiferous clays that can be correlated with the Genna Selole Fm of E Sardinia. This is followed by massive dolostones (Bathonian-Callovian) that can be correlated with the Dorgali Fm and covered by fossiliferous limestones similar to the Genna Silana Fm. This succession thus has a strong affinity with its E Sardinia Jurassic counterpart.

Northwards, in E Alpine Corsica, a rifted margin succession developed during the Middle to Late Jurassic. It features outer shelf limestones passing laterally, first to megabreccias, and finally to pelagic successions (Peybernès et al., 2001). The thickness of the megabreccias and the pelagic character of the succession grow up Eastwards, closing to the spreading Tethys. Ophiolites are recorded in the Easternmost successions (Peybernès et al., 2001).

Despite the lack of Early Jurassic deposits, pebbles of Early Jurassic carbonates have been found in the lower part of the E "Alpine Corsica" successions ("Breches vertes", "Breches rouges", "Breches de Francardo": Beauvais and Rieuf, 1981; Peybernès et al., 2001). As in E Sardinia, their absence can be correlated with the erosion related to the extensional tectonics leading to the opening of the Alpine Tethys.

A reconstruction of the E margin of the Sardinia-Corsica block during the Middle-Late Jurassic has been proposed by Costamagna et al. (2007).

\section{Discussion: the Eastern Sardinia-Corsica High}

In the past, several authors (e.g. Vardabasso, 1959) have hypothesized the presence of a continental ridge separating the W and E Mesozoic Jurassic Sardinian domains (an area forming the SW continuation of the so-called "Vindelician ridge" or "land" of continental Europe, largely emergent from the late Variscan to the Jurassic: Ziegler, 1990). However, they were never able to confirm their proposals due to the existence of limited dataset. Furthermore, in their synthesis 




Fig. 19.- Geological sketch of Corsica. Legend: 1) Punta Calcina; 2) Chiappa conglomerates.

on the Sardinian Mesozoic, Vardabasso (1959) and Cherchi and Schroeder (1986a) proposed that the W and E Sardinian Mesozoic domains were separated during the Triassic - Middle Jurassic. This hypothesis was also endorsed by Faure and Peybernès (1983).

Our dataset suggests that any separation between $\mathrm{W}$ and E Sardinia was only effective in the lower Middle Jurassic, as indicated also by the age of the shallowing carbonates of Aalenian-Bajocian age in the NW Sardinia area (Cherchi and Schroeder, 1986a), suggesting coeval uprising movements.

During the Triassic and Early Jurassic, the Mesozoic sedimentation in Sardinia was characterized by a moderate sedimentation rate and significant homogeneity all over the island (Costamagna and Barca, 2002; Jadoul et al., 2010). During the early Middle Jurassic (Aalenian), ("Sardo-Provencal domain": Durand Delga and Peybernès, 1986) when marine sedimentation was temporarily replaced in W Sardinia by paralic to lagoonal sedimentation due to the shallowing environment, the E Sardinia - Corsica area ("Extra-Alpine Domain": Durand Delga and Peybernès, 1986) emerged and was subjected to erosion, creating the Alpine Tethyan unconformity. We hypothesize that there was a limited uplift of this area, of no more than 200 to $300 \mathrm{~m}$ above sea level, otherwise the detritic succession at the base of the Jurassic succession would have been thicker, also considering the post-depositional compaction rate of conglomerates, sandstones and finer deposits (Kukal, 1990). We assume, based on the facies affinity, that the eroded thicknesses of the older successions (only the Middle Triassic to the Early Jurassic; the Carboniferous to Permian successions were almost totally dismantled by the previous erosional cycles) were possibly comparable with the thicknesses of the nearby Triassic and Early Jurassic successions in W Sardinia: less than $200 \mathrm{~m}$ for the Triassic succession (Costamagna and Barca, 2002) and a little more than $200 \mathrm{~m}$ for the Early Jurassic succession (Faure and Peybernès, 1983). These values are consistent with the erosive rates of carbonate rocks under warm-humid conditions in a time span of $12 \mathrm{Ma}$ (Aalenian-Bathonian?) (Kukal, 1990). Accordingly, the levelled lower surface of the Alpine Tethyan unconformity developed in this way (Fig. 20a, b); the erosion removed almost all the Triassic and Early Jurassic sediment, along with perhaps some of the previously sheltered remains of the Carboniferous to Permian deposits and part of the metamorphic rocks of the Variscan basement. The erosion of the post-Variscan succession is confirmed by pebbles of Early Jurassic, Triassic and Permian rocks found in the basal conglomerates of the Genna Selole Fm (Fig. 6) and the clastic part of the basal Middle Jurassic Corsica succession. The Triassic deposits were partially preserved and only in the SW rim of the E Sardinia high (Fig. 5); that were located on the slope of the rising high and sheltered in the footwall zone of normal faults (Fig. 4). This part thus only rose partially and suffered minor erosion.

It would also be plausible to suggest that, during the Bathonian tectonics, the E Sardinia-Corsica area belonged to the rising part of a tilted block that was related to an E-verging listric fault that delimited the block itself Westwards. However, this model would not account for the Eastwards, gradual, heterochronous sinking of the area, the radial flow pattern (imbrications) of the Genna Selole Fm from well-defined areas, or the paleomorphology of the highs and lows evidenced by the Genna Selole Fm isopachs (Figs. 9, 15, 20).

The uplift of the E Sardinia high occurred along old Variscan, previously compressive, tectonic structures (Fig. 4). So, a levelled, peneplaned surface made of almost only Variscan metamorphics was created by erosion. The presence, composition and comparison of the previously described Genna Selole Fm's stratigraphic sections evidence the roughness of the transgressed basement, showing low swells and shallow 


\section{Paleo-Europe Margin}

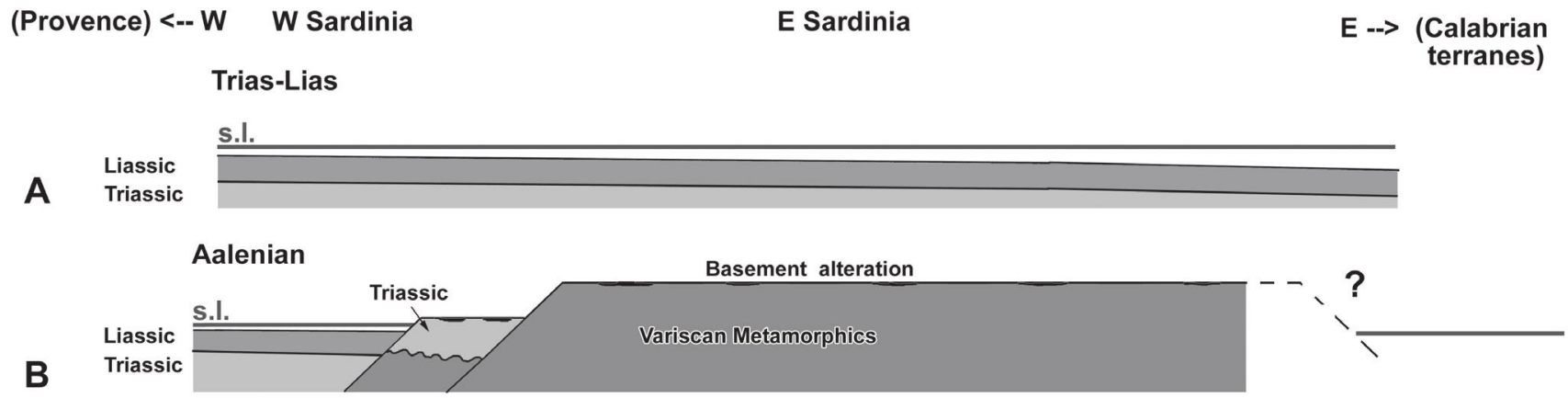

\section{Bajocian-Bathonian}

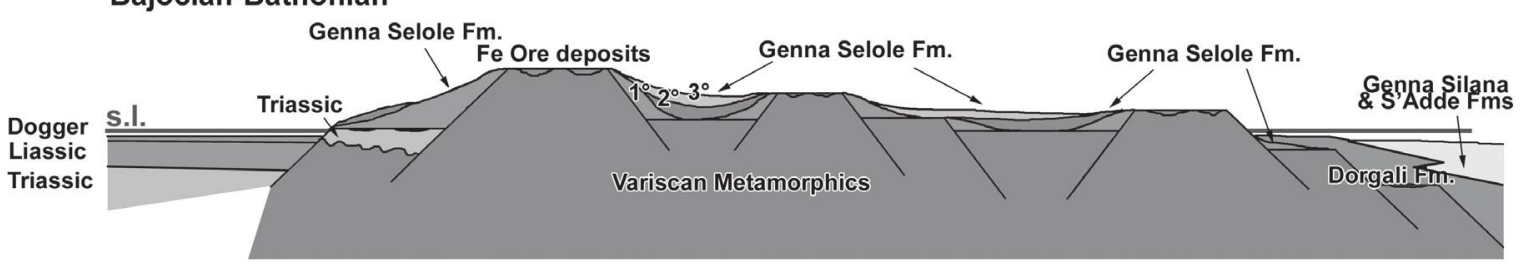

\section{Late Bathonian}

D

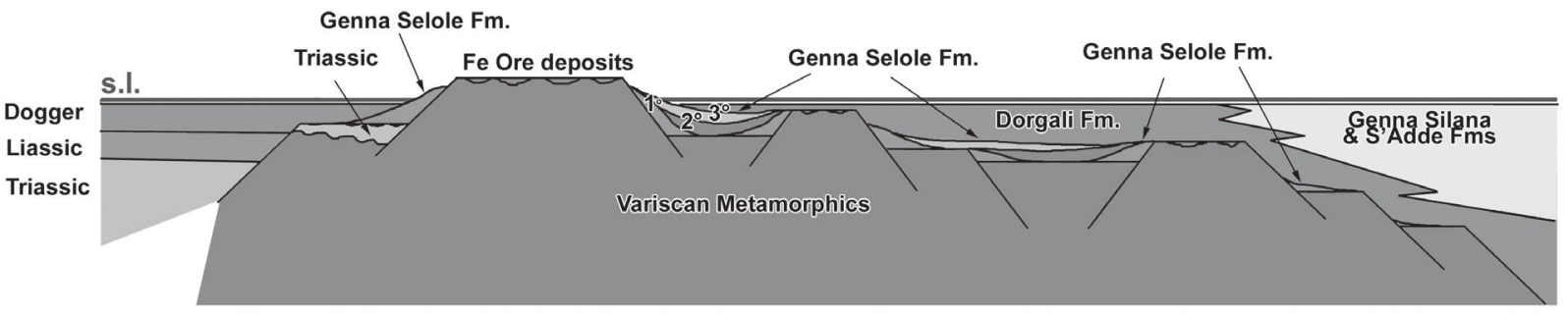

\section{Callovian}

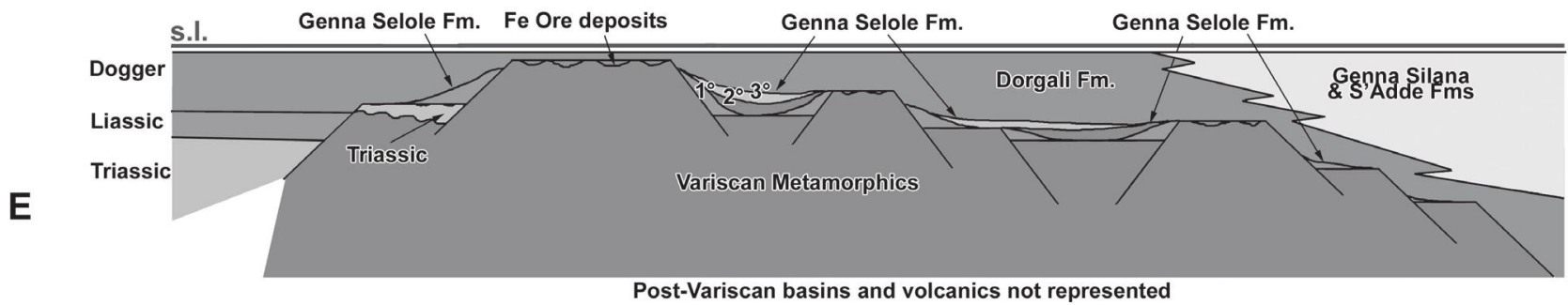

Fig. 20.- Paleogeographic profiles of the Eastern Sardinia part of the tectonic high. A) Middle Triassic to Early Jurassic: a single carbonate shelf extends all over the island. B) Aalenian: the Eastern Sardinia High rises and suffers erosion that dismantles the Early Jurassic and Triassic deposits, the residual patches of the Permian cover and part of the Variscan basement itself that someplace suffers pedogenization. C) Bajocian-Bathonian: the high brokes in minor horst and graben tectonic structures: the horst tops are mainly subjected to pedogenization, the slopes are eroded and feed debris downslope, the graben are filled by debris forming the Genna Selole Fm; the Genna Selole Fm deposits fine upwards according with the smoothing of the relief. D) The marine transgression steps over the basement starting from the NE (according to the oldest marine deposits) and invade the lower areas of the high moving gradually southwards. The pedogenetic laterites of the NE area are the less developed for their shorter time of emersion. E) In the end, the marine deposits cover completely the Eastern Sardinia high. Legend: 1) Lower Laconi-Gadoni Genna Selole Lithofacies; 2) Intermediate Nurri-Escalaplano Lithofacies; 3) Upper Ussassai-Perdasdefogu Lithofacies. s.l.: sea level. Post-Variscan basins and volcanics not represented.

scours whose development is related to the limited activity of older reactivated lines. It also proves the control of the depth of the scours over the composition of the filling unit. Variable alterations and pedogenization from place to place over the Variscan basement surface that forms the bed of the unconformity suggest the variable timespan of its subaerial exposition, which was usually shorter on the Northernmost outcrops. This point is proved by the slightly older age (Bathonian vs. Bajocian) of the first marine deposits resting over the unconformity in the $\mathrm{N}$ areas. 
The initial uplift is possibly coeval with the first regression events in the Nurra area (Aalenian: Ashraf et al., 1984), and is certainly younger than the Early Jurassic pebbles found in the Corsica successions (Beauvais and Rieuf, 1981; Peybernès et al., 2001), the main high was dissected along the former compressive Variscan lineaments (this activity in this period is testified by the matching synsedimentary faults in the Genna Selole Fm). The fragmentation gave rise to minor horst and grabens, with only moderate (about 200 to $300 \mathrm{~m}$ ?) morpho-tectonic relief (Fig. 20c), as suggested by considering the maximum thickness of the graben-filling, transgressive Genna Selole Fm, the eroded debris carried out of the area, and the compaction of the Genna Selole Fm siliciclastic grains showed by the analysis of the thin sections. Indeed, the thickness of the siliciclastic transgressive unit (fed by the erosion of the transgressed basement) that fills the irregularities represents only a part of the difference in height as the transgressed landscape, particularly considering the soluble element of the debris, with previous covers being largely composed by carbonates. This height difference tended to smooth down gradually northwards in E Sardinia (Figs. 21, 22).

The horst-tops were colonized by tropical lush vegetation due to the local warm-humid climate, as indicated by their
Fig. 21.- Minor structural horsts on the Eastern Sardinia high inferred by the sedimentary features (flow directions, thickness of the conglomeratic part of the unit less than $3 \mathrm{~m}$, alteration at the lower surface of the unconformity) of the Genna Selole Fm. The symbol “+” indicates the areas where the Genna Selole Fm is thicker.



Fig. 22.- Scheme of the correlation between the transgressed landscape and the transgressive siliciclastic unit filling the irregularities: A) Creation over a peneplain of a small-scale irregular landscape due to an extensional tectonics. B) Dismantling of part of the upper, relieved peneplain and filling of the depressions by the debris. C) Final marine transgression and regularization of the depositional surface. The final thickness of the GSF unit (d') represents only a part of the initial height difference (d). VB: Variscan basement. GSF: Genna Selole Fm; LG: Laconi-Gadoni Lithofacies; NE: Nurri-Escalaplano Lithofacies; UP: Ussassai-Perdasedefogu Lithofacies; DF: Dorgali Fm. PD: Pedogenesis. 
palynologic and plant assemblages (Del Río, 1984; Rees et $a l ., 2000)$ and the pedogenetic evidence (laterites and calcretes). The horst flanks supplied debris for the rapid infilling of the grabens, preventing pedogenesis there. Conversely, the tops of the minor horsts were only covered by the sediments when the morphology was completely smoothed by the Genna Selole Fm sediment fill (Figs. 20d, e and 22). Consequently, they suffered from stronger pedogenization processes. The sedimentation in the grabens begins with the rise of the main horst. Its lifespan was short: the main horst began to collapse almost immediately. This triggered the gradual marine transgression over the E Sardinia - Corsica high (represented by the Usassai-Perdasdefogu lithofacies) that ultimately covered the lower continental siliciclastic sediment of the Genna Selole Fm, or, where it is missing, the Variscan basement. The collapse started $\mathrm{N}$-wards, as testified by the older age of the first marine deposits (Bathonian condensed successions of NE Sardinia: Dieni and Massari, 1985b; and Punta Calcina, Southern Corse: Peybernès et al., 2000).

The thickness and facies of the Genna Selole Fm vary with the morpho-structural architecture of the substrate: in small, shallow basins, the Genna Selole Fm was thin and formed only by fine, usually immature, siliciclastics followed by carbonate deposits. Where the sub-basins were wider and more subsiding, the Genna Selole Fm was thicker and developed all its lithofacies, with mature coarse-grained deposits (alluvial fans) expanding towards the centre of the sub-basin itself (Fig. 5).

The collapse of the E Sardinia - Corsica High was gradual: the structural lows were the first to be flooded by the sea, resulting in a row of small islands instead of one wide, elongated island (Fig. 20d), before the final drowning (Fig. 20e). The presence of paleokarstic features in the limestones of the topmost Genna Selole Fm lithofacies suggests ephemeral emersions punctuating the subsiding trend (Costamagna, 2015).

Tectonic activity was intense during the deposition of the Genna Selole Fm, which is proved by the sedimentary evidence of coeval, strong seismic episodes.

The compositional and textural maturity of the siliciclastic part of the Genna Selole Fm decreases gradually northwards along with the thickness and heterogeneity of the unit. This could be related to a northwards shorter development of the fluvial network, implying a shorter subaerial exposure time and erosion of the $\mathrm{N}$ part of the high. In fact, as stated previously, based on the different biostratigraphic ages of the Middle Jurassic marine transgression in the SW and NE, the rise-and-fall cycle of the high is shorter northwards. Here, perhaps, the absence of the pre-Middle Jurassic sedimentary cover and the reworking of their quartzose conglomerate levels could also have some importance in terms of the composition and facies of the unit.

In the southernmost areas of the island, the Genna Selole Fm is thicker and rests over low-grade metamorphites. Here, the abundant monocrystalline rounded quartz debris and rare schists, metavolcanics, Permian porphyric granites, and Triassic carbonate pebbles suggest the erosion of a former post-
Variscan Carboniferous to Triassic sedimentary succession with quartz-rich conglomerates at its base. This implies the recycling of the quartz clasts. In the $\mathrm{N}$ areas, where the Genna Selole Fm is usually thin and overlies medium to high-grade metamorphites, the dominant presence of polycrystalline angular quartz debris associated with micaschist and gneiss pebbles indicates a local source of debris, with the quartz being derived from the high-grade metamorphites; here, it is probable that no sedimentary post-Variscan succession was ever sedimented.

Furthermore, the debris transport here was short. This suggests the limited development of the fluvial network, which was related to the moderate height of the tectonic high.

The dominant quartzose composition of the deposits suggests their provenance from a mature landscape. In the plots of Dickinson et al. (1983), almost all the investigated samples fall along the right side of the triangle, from the "craton interior" field to the "lithic recycled orogen" field (Fig. 17). Moreover, from the $\mathrm{S}$ to the $\mathrm{N}$ sectors, the clast composition gradually evolves from the top of the plot to its right-hand corner. This evidences a minor reworking of the substratum below the S-N direction, as well as the decreasing maturity of the covering Genna Selole Fm sediments.

The distribution map of the basal polygenic conglomerates of the Genna Selole Fm depicts a pattern of minor highs and lows in the entire E Sardinia horst: the main example is the Barbagia high (Fig. 9) (Costamagna and Barca, 2004). Accordingly, the composition of the lower Genna Selole Fm, as well as its thickness and paleocurrent directions, allows us to provide evidence for the morphology of the main high, and to highlight minor horsts and grabens over its surface (Fig. 21). Minor horsts form the Barbagia, Ogliastra, Supramonte, and Posada highs. The development of these highs is further supported by the presence of pedogenetic profiles (laterites: Marini, 1984) in areas where the Genna Selole Fm is almost absent, while the first Middle Jurassic deposits are impure carbonates of the Ussassai-Perdasdefogu lithofacies; these are interpreted as the areas where the continental conditions persisted for a longer timespan.

Based on the chronostratigraphical data on the youngest eroded deposit (Middle Triassic pebbles, Sardinia; Early Jurassic pebbles, Corsica, Peybernès et al., 2001) and the oldest sedimentary transgression sensu Busson 1982 (palustrinecoastal deposits of the Nurri-Escalaplano lithofacies of the Genna Selole Fm, Bajocian: Dieni et al., 1983), it can be inferred that, unlike previous interpretations (e.g. Vardabasso, 1959; Cherchi and Schroeder, 1985a), the paleogeographic separation from $\mathrm{W}$ and $\mathrm{E}$ Sardinia only existed during the early part of the Middle Jurassic: in fact, evidences of Middle Triassic to Early Jurassic removed sedimentary cover have been found as pebbles in the conglomerates of eastern Sardinia and Corsica..

Casellato et al. (2012) and Jadoul et al. (2010) hypothesize about the gradual growth of several isolated shallow carbonate bodies that merged later in E Sardinia during the late Mid- 
dle Jurassic. The basement horsts, which remained shallow, were the ideal loci for the birth of a carbonate factory (Fig. 20e). Sparse terrigenous clastics in the carbonates suggest the local persistence of emerged areas.

Many uplift phases developed successively in Sardinia after the Variscan orogenic cycle. This is suggested by tens of metres-thick, unconformable conglomeratic levels evidencing unconformities that are located at the base of the sparsely distributed remains of Carboniferous, Permian and Triassic successions that are well-dated (Cassinis et al., 2000 and references therein; Cassinis and Ronchi, 2002; Ronchi et al., 2008). Each conglomeratic level suggests a time of erosion of the reliefs. The so-called Variscan peneplain originated from the superposition of several erosion surfaces that developed on more or less articulate morphologies at different times. We therefore suggest that the present levelled, weakly undulate and irregular surface (Alpine Tethydian unconformity) upon which the Jurassic succession of E Sardinia currently rests is, in the main, the "Alpine" reworking of the former, repeatedly exhumed and reworked, first Variscan peneplain.

\section{Comparisons with Middle Jurassic close areas}

The events documented in the Sardinia-Corsica area during the Middle Jurassic can be correlated with neighbouring W Mediterranean regions located both SE and NW of the Alpine Tethys ridge opening (Fig. 23).

\subsection{Spain}

During the Middle Jurassic, some fault-controlled carbonate platforms to the $\mathrm{E}$ of the Hesperian Massif of the Iberian Plate formed the domain of the Iberian and Catalan coastal ranges of E Spain (Goméz and Fernandez-Lopez, 2006, and references therein). This area was located between the Iberian Variscan and the Sardinia-Corsica-Brianconnais.

These Iberian platforms flanked the corridor that connected the Alpine Tethys shelves with the Central Atlantic Ocean. During the Middle Jurassic, the Iberian Basin was formed by a system of tectonically-controlled epicontinental carbonate platforms. Footwall blocks in the extensional system formed palaeogeographic highs hosting shallow-water environments. There were open-marine environments in the areas between these highs, where low-energy ammonite-bearing facies developed. This indicates that they were somewhat connected to the open ocean. Reactivations of normal faults in the area at this time, and their link to extensional movements leading to the $\mathrm{W}$-wards extension of Tethys, were also proposed by Aurell et al. (2003). Nonetheless, in addition to the mentioned tectonics, frequent shifts of the shoreline suggest the influence of regional, or even global, sea level changes.

In any event, none of these blocks ever suffered enough of an uplift to enable them to emerge. This is probably because they were located well away from the Alpine Tethys spreading area. After the Middle Jurassic, their evolution was re-

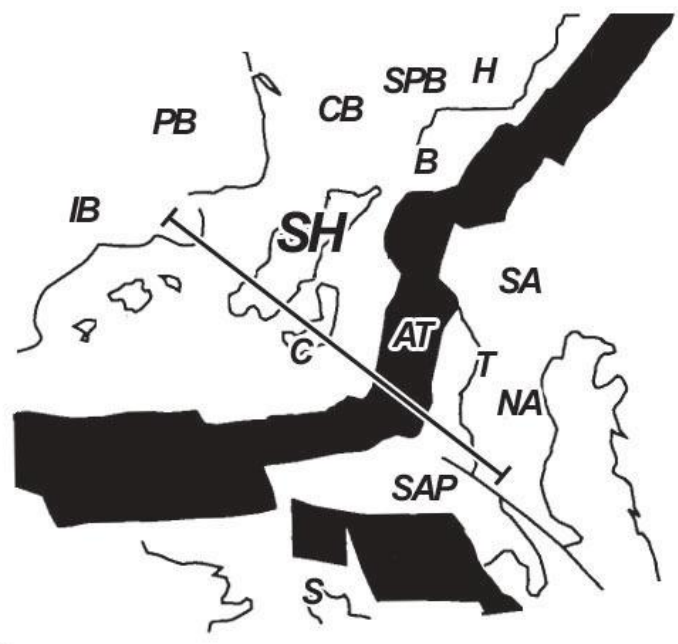

NW

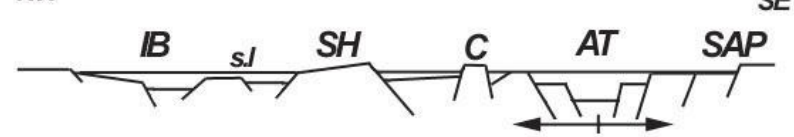

Fig. 23.- Paleogeography of the Western Mediterranean area, schematic cross section and location of the Eastern Sardinia-Corsica high $(\mathrm{SH})$ during Bajocian-Bathonian (redrawn and modified from Santantonio and Carminati, 2012). AT: Alpine Tethys; B: Brianconnais; C: Calabria; CB: Causses Basin; CO: Corsica; H: Helvetian; IB: Iberian Basin; NA: Northern Apennines; PB: Pyrenean basin; S: Sardinia; SA: Southern Alps; SAP: Southern Apennines; SPB: South Provence Basin; S: West Sicily; T: Tuscany.

lated to a shallow shelf environment with limited fluctuations of the sea level (Badenas and Aurell, 2001).

\subsection{Southern France}

This area pertained to the Iberian plate (Aurell et al., 2003). Located here during the Jurassic period were the S Provence sub-basin (Leonide et al., 2007) and the Grand-Causse basin (Philippe et al., 1998).

The S Provence sub-basin started during the Early Jurassic in response to the early Alpine Tethys opening that fragmented a single shelf area into several physiographical units ("Ligurian rifting cycle": de Graciansky et al., 1998). This basin was almost triangular and became structured in enclosed grabens or minor basins limited by NNE-SSW main faults. The carbonate sedimentation dominated. Each sub-basin displays its own story of alternated uplifts and sinkings in relation to the tectonic activity. From the Early to the Middle Jurassic, the depositional environment fluctuated irregularly from the supratidal to the offshore. The main tectonic influence over the sedimentation was explicated during the early Middle Jurassic: erosion surfaces are evident over crests of tilted blocks. This sea level fall is referred to a tectonic uplift that is related to the Aalenian Mid-Cimmerian phase (Ziegler, 1990; de Graciansky et al., 1993). Later, the environmental conditions return to shallow marine, and a period of progressive, but limited, deepening starts, locally reaching offshore conditions. 
The Grand Causse basin (Ciszak et al., 1999) follows a similar path during the Jurassic: a basin that is tectonicallyinfluenced by the Alpine Tethys opening is ruled by important normal faults in which the carbonate depositional environment shifts irregularly from the shallow to the outer shelf. The main feature of this basin succession is the presence of emersion events from the Aalenian and the fact it reached a climax during Bajocian-Bathonian times. These events led to important erosive surfaces, paleosoils, rooted horizons, subsurface paleokarsts (Charcosset et al., 2000), and the development of low-energy continental, palustrine and carbonate swamp environments in which a rich microfloristic association has been found and analyzed (Philippe et al., 1998). This further supports the paleoenvironmental reconstruction.

\subsection{Brianconnais domain}

During Mesozoic times, the Brianconnais domain was part of the Iberian plate and constituted the $\mathrm{E}$ continuation of the Sardinia-Corsica sector (Stampfli, 1993). Due to the developing Alpine extensional tectonics (Bourbon et al., 1973; Lualdi, 1985; 1994; Bertok et al., 2011; de Graciansky et al., 2011; Costamagna, 2013b), the area emerged repeatedly between the Middle Triassic and Middle Jurassic.

In the Ligurian Brianconnais (Lualdi, 1985, 1994; Decarlis et al., 2013), the carbonate deposits of the S. Pietro ai Monti Fm (Ladinian) are unconformably covered by thin discontinuous deposits made of conglomerates, blackish marlycarbonaceous schists and black sandy marls (Rhetian?). The inner to outer shelf limestones of the Rio di Nava Fm (Bathonian) follow unconformably, starting with continental carbonate breccias with Fe-oxide recirculations. This unit is in turn unconformably covered by the pelagic limestones of the Val Tanarello Fm (Berriasian-Kimmeridgian?).

In the Southern Brianconnais area (Costamagna, 2013b), the shallow carbonates of the Rocca la Meja Fm (AnisianLadinian) and the carbonates and evaporites of the Cargneules supérieur (Carnian) are unconformably covered by a coarse carbonate breccia forming the base of the platform carbonate schists of the "Dogger a Mytilus" (Bathonian-Callovian). They are rapidly followed by the Marbres de Guillestre (Oxfordian-Tithonian), which is deposed in pelagic environments related to a quick sinking.

Consequently, in the entire Brianconnais area, a persisting tectonic instability from the Middle-Late Triassic to the Middle Jurassic led to the erosion (possibly during separate stages) of almost all the Late Triassic to Early Jurassic successions, as documented by the relationships between Triassic and Jurassic units. Nonetheless, the emerged area was never higher than some 10 s of metres. This is evidenced by the limited depth reached by the erosion and the limited development of the karstic network. Furthermore, after Middle Jurassic times, the entire area suffered a rapid collapse (Bourbon et al., 1973), as revealed by the Up- per Jurassic pelagic successions of the entire Brianconnais domain.

\subsection{Calabria-Peloritani area}

The precise whereabouts of the Calabria-Peloritani area with respect to the Sardinia-Corsica block during the Jurassic is still being debated. It was probably located SE of the Sardinia-Corsica block and close to it (Vai, 2001; Aldinucci et al. 2007; Álvarez and Shimabukuro, 2009). The Calabria-Peloritani area is a composite terrane forming an orogenic wedge that undertook Variscan and Alpine tectonics (Bonardi et al., 2001). It is formed by Variscan metamorphic rocks covered unconformably by Mesozoic to Tertiary deposits. Several tentative maps that attempt to unravel the original nature and setting of the different units forming the terrane have been published (e.g. Vai, 2001).

In the Calabrian arc, a Mesozoic key succession has been described in the Longobucco Group (Triassic-Jurassic boundary to Toarcian) (Young et al., 1986; Bouillin et al., 1988; Santantonio, 1993; Santantonio, 2012; Passeri et al., 2014). This succession evidences sedimentation on a rifted continental margin. It starts from continental siliciclastic fluvial deposits (red beds, Rhetian-Hettangian) that unconformably rest over Variscan metamorphics. It passes first to blackish limestones of the carbonate shelf (Sinemurian), then to marls of the shelf-edge or slope facies (Pleinsbachian), and, finally, to basinal turbidites with intercalated hemipelagites (Pleisnbachian-Toarcian). Santantonio (1993, 2012) described Toarcian extensional tectonics in the Caloveto Group, close to the Longobucco basin. The lateral setting of the mentioned deposits is probably due to a tilted block system that was similar to those that can be observed on continental passive margins. Accordingly, it is interpreted as the S-most remains of the W margin of the Alpine Tethys.

Recently Santantonio et al. (2016) investigated further in the Calabrian Longobucco basin the local siliciclastic to carbonate succession whose Jurassic tectonosedimentary evolution looks very similar to that delineated in the Sardinia-Corsica block. In fact, repeated emersions leading to erosion of Variscan highs and even more sudden catastrophic collapses and their influence over the sedimentation in the frame of the opening Tethys are described. They interpret this as a sinking fragment of the European-Iberian continental margin.

In the Peloritani area (Cecca et al. 2002; Catalano, 2009, and references therein), clastic deposits resting over Rhetian (?) red-beds in the Longi-Taormina unit gradually pass upwards to neritic black limestones (Hettangian-Sinemurian). The succession follows with the slope and pelagic deposits that are upper Early Jurassic to Oligocene in age. The presence of many neptunian dykes extending down to the Variscan basement suggests that extensional tectonics acted during and after Toarcian times. This evidences the closeness to the Alpine Tethys spreading area. The succession ends with Aquitanian siliciclastic turbidites (de Capoa et al., 1997). 


\subsection{Relationships between the Sardinia-Corsica block and surroundings areas: final considerations}

Through a comparison of the diverse Jurassic successions outcropping in the W Mediterranean area, we have managed to depict a paleogeographic frame of reference in which to place the Sardinia-Corsica block during this period (Fig. 23).

The Alpine Tethys gradually opened throughout the Jurassic period in the W Mediterranean area (Stampfli, 2000; Masini et al., 2013, and references therein). In the W-most areas (Iberian plate), the consequences were only minimal sea level fluctuations and ephemeral emersion times. In the French areas, meanwhile, the Bajocian-Bathonian emersions became more important.

The scenery gradually changes close to the Alpine oceanic ridge. During the Middle Jurassic, the Alpine Tethys opening first induced the emersion of the E Sardinia-Corsica high (while W Sardinia suffered only a limited shallowing), and then caused its rapid collapse (probably in connection with the Aalenian Mid-Cimmerian rifting phase: Ziegler, 1990; de Graciansky et al., 1993). Later, during the Late Jurassic, and while E Sardinia settled to outer ramp depths, pelagic successions suddenly took place in Corsica, suggesting rapid drowning.

During the Bathonian-Bajocian, the Brianconnais domain formed an elongated SW/NE-risen tectonic structure (Stampfli, 2000), as well as the E Sardinia - Corsica high. A Bathonian tectonic extensional phase is evidenced here by Bertok et al. (2011). The Brianconnais was also flanked E-wards by the spreading of the Alpine Tethys. As a consequence, its geodynamic development was similar to that of the E Sardinia - Corsica high (Bourbon et al. 1973; Bertok et al. 2011). However, its emersion was comparatively minor in terms of consequences and short-lived, and the depth reached here due to erosion and the amount of dislodged debris was therefore limited (it was also preserved in minor quantities for its exclusive carbonatic nature). On the other hand, unlike the Sardinian area, and more similar to the Corsica successions, the Brianconnais domain sunk in the Late Jurassic and was covered by pelagic successions.

Nonetheless, this entire E Sardinia - Corsica - Brianconnais tectonic structure possibly extended ENE up to the Bohemian Massif, thus dividing the European area from Tethys. Indeed, it may be regarded as the remains of the SW branch of the Vindelician ridge which, between Permian times and the Middle Jurassic, and with scattered interruptions due to the ephemeral drowning of alternate sectors, was a relieved, stable, flat-topped feature with a slow subsidence rate in comparison with surrounding, deeper areas. During its intermittent emersions, this feature supplied terrigenous material to the surrounding areas until the Jurassic (Ziegler, 1990).

The collapse developed earlier in the Calabria-Peloritani area and was stronger: pelagic successions took place from the Early Jurassic onwards (Bouillin et al., 1988; Cecca et al., 2002; Passeri et al., 2014). This indicates that the Calab-
ria-Peloritani terrain was closer to the Alpine Tethys oceanic ridge than the E Sardinia-Corsica high. A further Toarcian extensional phase is mentioned by Santantonio (1993, 2012).

Accordingly, the Alpine Tethyan unconformity is easily recognizable, and the evidence of active extensional tectonics is clear and well-developed along the entire E SardiniaCorsica-Brianconnais ridge. This evidence is earlier, quicker and more marked in the E-ward Calabria-Peloritani area. Evidence of tectonics is still well-visible also in the Southern French area. Instead, it fades in the surrounding, Wwards Iberian microplate areas where there is no emersion evidence; generally, emersions are replaced by simple shallowing trends. This is probably related to their great distance from the Alpine Tethys oceanic ridge.

As a consequence, unconformities, relationships between tectonics and sedimentation, and tectonic activity allow us to discriminate the variable closeness of the diverse areas - in this order: Spain, S France, Sardinia-Corsica-Brianconnais, and Calabria-Peloritani - to the Alpine Tethys spreading.

\section{Conclusions}

During the late Early- Middle Jurassic, extensional tectonics developed in the W Mediterranean area. It caused the opening of the Alpine Tethys Ocean and the development in the surrounding areas of distensive structures such as tectonic highs and lows, transitions from shallow to pelagic platforms, and basins.

In the Sardinia-Corsica block, which is located Westwards of the Alpine Tethys, a tectonic high extending from E Sardinia to Corsica rose and sunk during Aalenian to Bathonian times. As a result, the transgressive Genna Selole Fm buried and fossilized an eroded and sculptured morphostructure through the Alpine Tethyan unconformity. This structure was a previous quasi-tabular morphology mobilized by Jurassic extensional Alpine tectonics and modelled in minor highs and lows (horst and graben) (Fig. 5). The rise of the E Sardinia high was accompanied by its alteration under a warm-humid climate; while the minor highs were colonized by vegetation and developed a pedogenetic profile of variable thicknesses, the upper slopes fed debris to the lows. This led to the bottom being rapidly covered by coarse sediment, and was protected from the alteration phenomena. Accordingly, the local Genna Selole Fm stratigraphy, paleoenvironments and sediment composition was first strictly ruled by the topographic location of each other and second by the dimension of the basins that the unit filled. The Genna Selole Fm reaches maximum thickness and complexity in the lows: the wider and deeper the lows are, the more developed and articulated the unit is. The sedimentation of the Genna Selole Fm reached the morphological highs only when the lows were entirely filled by sediment (Figs. 5, 22). As a result, only transitional fine deposits and carbonate sediment can lie down over the high areas featured by thick pedogenetic, Fe-rich profiles. When the topographic profile was finally smoothed, the main collapse 
had already started and so the high sinking was ultimately completely covered by the marine, shallow to deep, carbonate sedimentation.

Comparisons with nearby areas provide evidence that the Sardinia-Corsica block was one of the areas most affected by the active extensional Alpine tectonics. In fact, these tectonics even led to the marked emersion of the E part of the block, thus causing the erosion of Early Jurassic, Triassic and, possibly, Variscan deposits; the main part of the older Carboniferous to Permian post-Variscan deposits had already been removed by previous erosive cycles. A similar story had developed even earlier in the eastwards-located CalabriaPeloritani area, closer to the Alpine Tethys ridge. Here, too, the Mesozoic succession rests directly and unconformably over the Variscan basement on a surface that is similar to the Alpine unconformity.

Accordingly, using growing tectonosedimentary signals in the W Mediterranean area, we can further support the increasing closeness, in order, of the Iberian areas, the Provencal sector, the Sardinia-Corsica-Brianzonese ridge, and the Calabria-Peloritani region to the spreading area of the Alpine Tethys (Fig. 23).

\section{Aknowledgements}

Suggestions of Andreas Schaefer (Bonn) and Franco Marco Elter (Genova) have been helpful. Discussions with Massimo Santantonio (Roma) have been deeply appreciated. The accurate review of Alessandro Decarlis and of an anonymous referee improved greatly the manuscript. Research founded by MiUR (ex-60\% L.G. Costamagna).

\section{References}

Abbate, E., Bortolotti, V., Conti, M., Marcucci, M., Principi, G., Passerini, V., Treves, B. (1986): Apennines and Alps Ophiolites and the evolution of the Western Tethys. Memorie della Società Geologica Italiana 31, 23-44.

Aldinucci, M., Gandin, A., Minzoni, N. (2007): The Tithonian-Berriasian carbonates of the Stilo Unit (Aspromonte, Calabria) and Capo Figari (NE Sardinia): depositional setting and paleogeographic significance. Rendiconti della Società Geologica Italiana 5, 35 .

Alvarez, W., Shimabukuro, H.D. (2009): The geological relationships between Sardinia and Calabria during Alpine and Hercynian times. Bollettino della Società Geologica Italiana 128, 257-268. DOI: 10.3301/IJG.2009.128.2.257

Amadesi, E., Cantelli, C., Carloni, G.C., Rabbi, E. (1960): Ricerche geologiche sui terreni sedimentari del foglio 208 Dorgali. Giornale di Geologia 2, 59-87.

Ashraf, A.R., Cherchi, A., Schroeder, R. (1984): Pollen und Sporen aus dem mittleren Dogger von NW-Sardinien (Italien). Palaeontographica Italica 192, 1-15.

Assorgia, A., Bentini, L., Biondi, P.P. (1974): Caratteristiche strutturali delle assise carbonatiche mesozoiche del Golfo di Orosei. Il sopramonte di Orgosolo - Urzulei. Memorie della Società Geologica Italiana 13(2), 209-19.

Assorgia, A., Gandolfi, R. (1975): Il sopramonte di Orosei (Golfo di Orosei, Sardegna) e la Gola di Gorropu. Osservazioni stratigrafiche e geomorfologiche sul Mesozoico affiorante, con particolare riguardo al Cretaceo Superiore e microfaune planctoniche. Bollettino della Società Geologica Italiana 94(6), 1723-1740.

Aurell, M., Robles, S., Badenas, B., Rosales, I., Quesada, S., Melendez, G., Garcia-Ramos JC (2003): Transgressive-regressive cycles and Jurassic palaeogeography of northeast Iberia. Sedimentary Geology 162(3), 239-271. DOI: 10.1016/S0037-0738(03)00154-4

Bàdenas, B., Aurell, M. (2001): Kimmeridgian palaeogeography and basin evolution of northeastern Iberia. Palaeogeography, Palaeoclimatology, Palaeoecology, 168, 291-310.

Barca, S., Costamagna, L.G. (1999): Riattivazione periodica di linee tettoniche erciniche come fattore di controllo sui cicli sedimentari mesoe cenozoici della Sardegna centro-meridionale. FIST - Geoitalia 1999, $2^{\circ}$ Forum Italiano di Scienze della Terra, Riassunti, Fasc.1, Bellaria 1999, 309-312.

Barca, S., Costamagna, L.G., Janssen, S., Von Der Handt, A. (2001): I bacini permiani tardo-ercinici della Sardegna centrale: nuove osservazioni paleogeografiche e tettoniche. FIST - Geoitalia 2001, $3^{\circ}$ Forum Italiano di Scienze della Terra, Riassunti, Chieti 2001, 203 204.

Beauvais, L., Rieuf, M. (1981): Dècouverte de Madrèporaires oxfordiens dans les calcaires de Caporalino (Corse). Bulletin Societé géologique de France 23, 353-359.

Bernoulli, D., Jenkyns, H.C. (1974): Alpine, Mediterranean and Central Atlantic Mesozoic facies in relation to the early evolution of the Tethys. In Dott. R.H. Jr., Shaver R.H. (Eds), Repr. from "Modern and ancient geosinclinal sedimentation", SEPM, Special Publication 19, 129-160.

Bertok, C., Martire, L., Perotti, E., D’Atri, A., Piana, F. (2011): Middle-Late Jurassic sinsedimentary tectonics recorded in the Ligurian Briançonnais succession (Marguareis-Mongioie area, Ligurian Alps, NW Italy). Swiss Journal of Geosciences 104, 237-255. DOI 10.1007/ s00015-011-0058-0

Bonardi, G., Cavazza, W., Perrone, V., Rossi, S. (2001): Calabria-Peloritani Terrane and Northern Ionian Sea. In: Vai G.B., Martini I.P. (eds,), Anatomy of an Orogen: the Apennines and Adjacent Mediterranean Basins. Kluwer Academic, Dordrecht, pp. 287-306.

Bouillin, J.P., Mouterde, R., Olivier, P., Majesté-Menjoulas, C. (1988): Le Jurassique de Longobucco (Calabre, Italie), à la jonction de la Téthys ligure et de la Téthys maghrebine. Bulletin Societé géologique de France 4(1), 93-103.

Bourbon, M., de Graciansky, P.C., Megard-Galli, J., Lemoine, M. (1973): L'évolution paléogéographique du domaine briançonnais au Mésozoique: carbonates de plate-forme subsidente, révolution du Lias supérieur, instauration progressive d'un regime pélagique profond. Comptes Rendus Academie des Sciences Paris 277, 769-772.

Busson, G. (1982): Le Trias comme période salifère. Geologische Rundshau, 71(3), 857-880.

Carmignani L, Carosi R, Di Pisa A, Gattiglio M, Musumeci G, Oggiano G, Pertusati PC (1994) - The Hercynian chain in Sardinia. Geodinamica Acta 7, 31-47.

Carmignani, L., Oggiano, G., Barca, S., Conti, P., Eltrudis, A., Funedda, A., Pasci, S., Salvadori, I. (2001): Geologia della Sardegna (Note illustrative della Carta Geologica della Sardegna in scala 1:200.000). Memorie descrittive della Carta Geologica d'Italia, Servizio Geologico Nazionale. Istituto Poligrafico e Zecca dello Stato, Roma. pp. 284.

Carosi, R., Frassi C., Iacopini D., Montomoli C. (2005): Post collisional transpressive tectonics in Northern Sardinia (Italy). Journal of the Virtual Explorer 9, 3.

Casellato, C.E., Jadoul, F., Lanfranchi, A. (2012): Calcareous nannofossil biostratigraphy of the S'Adde Limestone (Mt. Albo, Orosei Gulf): insights into the Middle-Late Jurassicispien margin evolution. Rivista Italiana di Paleontologia Stratigrafica 118, $439-460$ 
Cassinis, G., Cortesogno, L., Gaggero, L., Pittau, P., Ronchi, A., Sarria, E. (2000): Late Paleozoic continental basins of Sardinia. Field Trip Guidebook. Intern. Field Conf. on the continental Permian of the Southern Alps and Sardinia (Italy). Regional reports and general correlations. Brescia, 15-25 Sept. 1999, pp. 116.

Cassinis, G., Ronchi, A. (2002): The (Late-) Post-Variscan continental successions of Sardinia. Rendiconti della Società Paleontologica Italiana 1, 169-176.

Catalano, S. (Ed.) (2009): Note illustrative alla Carta Geologica d'Italia alla scala 1:50000, Foglio 613 Taormina. Università degli Studi di Catania, pp.151.

Cecca, F., Crivelli, S., de Capoa, P., Di Staso, A., Giardino, S., Messina, A., Perrone, V. (2002): Nouvelle datation et interprétation de la succession sédimentaire de Fiumara Sant'Angelo (Monts Péloritains; Italie méridionale): conséquences pour la paléogéographie mésozoïque de la Téthys Mediterranéenne. Bulletin Societé géologique de France 173(2), 171-184.

Charcosset, P., Combes, P.J., Peybernés, B., Ciszak, R., Lopez, M. (2000): Pedogenic and karstic features at the boundaries of Bathonian depositional sequences in the Grands Causses area (Southern France): stratigraphic implications. Journal of Sedimentary Research 70, 255264. DOI: $1073-130 \mathrm{X} / 00 / 070-255$

Cherchi, A., Schroeder, R. (1986a): Mesozoic of Northwestern Sardinia. Stratigraphy. In: Cherchi, A. (ed.). 19th Micropal Coll, Guide-Book, Sardinia, October 1985, 44-56.

Cherchi, A., Schroeder, R. (1986b): Bajocian of Monte Vaccargiu. In: Cherchi A. (ed.), 19th Micropal Coll, Guide-Book, Sardinia, October 1985, 146-150.

Ciszak, R., Peybernés, B., Thierry, J., Faure, P. (1999): Sinthése en termes de stratigraphie sequéntielle du Dogger et de la base du Malm dans les Grands Causses. Geologie de France 4, 45-58.

Costamagna, L.G. (2013a): Transgressive evolution and paleoenvironments of a mixed depositional system in a tectonically-active context: the early Middle Jurassic of Eastern Sardinia. JMES Special Issue, 45-48 (XI GeoSed).

Costamagna, L.G. (2013b): Middle Triassic carbonate lithostratigraphy of the Southern Briançonnais (Cottian Alps, Italy) and comparison with the surrounding areas. GeoActa 12, 1-24.

Costamagna, L.G. (2015): Middle Jurassic continental to marine transition in an extensional tectonics context: the Genna Selole Fm depositional system in the Tacchi area (Central Sardinia, Italy). Geological Journal. Published online in Wiley Online Library (wileyonlinelibrary.com). doi: 10.1002/gj.2680.

Costamagna, L.G., Barca, S. (2002): The Germanic Triassic of Sardinia: a stratigraphic, sedimentological and paleogeographic review. Rivista Italiana di Paleontologia Stratigrafica 108, 67-100.

Costamagna, L.G., Barca, S. (2004): Stratigrafia, analisi di facies, paleogeografia ed inquadramento regionale del Giurassico dell'area dei Tacchi (Sardegna centro-orientale). Bollettino della Società Geologica Italiana 123, 477-495.

Costamagna, L.G., Barca, S., Del Rio, M., Pittau, P. (2000): Stratigrafia, analisi di facies deposizionale e paleogeografia del Trias del Sarcidano-Gerrei (Sardegna SE). Bollettino della Società Geologica Italiana 119, 473-496.

Costamagna, L.G., Barca, S., Lecca, L. (2007): The Bajocian-Kimmeridgian Jurassic sedimentary cycle of eastern Sardinia: stratigraphic, depositional and sequence interpretation of the new "Baunei Group". Comptes Rendus Geoscience 339, 601-612.

Costamagna, L.G. (2013a): Transgressive evolution and paleoenvironments of a mixed depositional system in a tectonically-active context: the early Middle Jurassic of Eastern Sardinia. Journal of Mediterranean Earth Sciences, Special Issue 45-48 (XI GeoSed).

Costamagna, L.G. (2013b): Middle Triassic carbonate lithostratigraphy of the Southern Briançonnais (Cottian Alps, Italy) and comparison with the surrounding areas. GeoActa 12, 1-24.

D’Argenio, B., Carannante, G., Simone, L. (1986): Sedimentary evolution of the Northwestern Sardinia Jurassic and Cretaceous carbonates. In: Cherchi, A. (ed.), 19th Micropal Coll, Sardinia, Italy, October 1985, Guide book, 57-65.

Decarlis A., Dellagiovanna G., Lualdi A., Maino M., Seno S. (2013): Stratigraphic evolution oin the Ligurian Alps between Variscan heritages and the Alpine Tethys opening: a review. Earth Science Reviews 125, 43-68.

de Capoa P, Guerrera F, Perrone V, Serrano-Lozano F (1997) - New biostratigraphic data on the Frazzanò Formation (Longi-Taormina Unit): consequences on the deformation age of the Calabria-Peloritani Arc Southern Sector. Rivista Italiana di Paleontologia Stratigrafica 103, 343-356.

de Graciansky, P.C., Dardeau, G., Dumont, T., Jacquin, T., Marchand, D., Mouterde, R., Vail. P.R. (1993): Depositional sequence cycles, transgressive-regressive facies cycles, and extensional tectonics: example from the southern Subalpine Jurassic basin. Bulletin Societé géologique de France 164, 709-718.

de Graciansky, P.C., Jacquin, T., Hesselbo, S.P. (1998): The Ligurian cycle: an overview of lower Jurassic 2nd-order transgressive/regressive facies cycles in western Europe. In: de Graciansky, P.C., Harenbol, J., Jacquin, T., Vail, P.R. (eds.), Mesozoic and Cenozoic sequence stratigraphy of European basin. SEPM Society for Sedimentary Geology, Special Publication 60, 467-479.

de Graciansky, P.C., Roberts, D.G., Tricart, P. (2011): The Western Alps, from Rift to Passive Margin to Orogenic Belt: An Integrated Geoscience Overview. Elsevier, $432 \mathrm{pp}$.

Dickinson, W., Breard, L., Brakenridge, G., Erjavec, J., Ferguson, R., Inman, K., Knepp, R., Lindberg, F., Ryberg, P. (1983): Provenance of North American Phanerozoic sandstones in relation to tectonic setting. Geological Society American Bulletin 94, 222-235.

Del Río, M. (1976): Analisi palinologica del Giurese della Sardegna centrale. Bollettino della Società Geologica Italiana 95, 619-631.

Del Rio, M. (1984): Palynology of the Middle Jurassic black organic shale of 'Tacco di Laconi', Central Sardinia, Italy. Bollettino della Società Paleontologica Italiana 23 (2), 325-342.

Del Rio, M. (1990): Palynological investigation in the Middle Jurassic of Nurra (Sardinia, Italy). Dip. Scienze Terra, Cagliari, pp. 48.

Dieni, I., Fischer, J.C., Massari, F., Salard-Cheboldaeff, M., VozeninSerra, C. (1983): La succession de Genna Selole (Baunei) dans le cadre de la paléogéographie mésojurassique de la Sardaigne orientale. Memorie di Scienze Geologiche, Padova 36, 117-148.

Dieni, I., Massari, F. (1982): Presence de glaucophane detritique dans le Maastrichtien inferieur de Sardaigne orientale. Implications geodynamiques. Comptes Rendus Academie Science Paris 295, 679-682.

Dieni, I., Massari, F. (1985a): Mesozoic of Eastern Sardinia. in: Cherchi A. (ed.), 19th Micropal Coll, Guide-Book, Sardinia, October 1985, 66-77.

Dieni, I., Massari, F. (1985b): Bathonian-Oxfordian of Posada. in: Cherchi A. (ed.), 19th Micropal. Coll, Sardinia, Italy, October 1985, Guide book, 201-206.

Dieni, I., Massari, F., Radulovic, V. (2013): The Mt Perda Liana section (Middle Jurassic, Central-Eastern Sardinia): revised stratigraphy and brachiopod faunas. Bollettino della Società Paleontologica Italiana 52, 123-138. doi:10.4435/BSPI.2013.21

Durand-Delga, M., Peybernés, B. (1986): Reconstitution d'une succession mesozorque de type sarde-provencal en Corse méridionale par l'étude des galets des conglomérats tertiaires de la ragion de Porto-Vecchio. Comptes Rendus Academie des Sciences Paris, Ser. II 303(9), 843-850.

Fabbi, S., Santantonio, M. (2012): Footwall progradation in syn-rift carbonate platform slope systems (Early Jurassic, Northern Apennines, Italy). Sedimentary Geology 281, 21-34. DOI.org/10.1016/j.sed- 
geo.2012.07.008

Faure, P., Peybernés, B. (1983): Le Lias de la Nurra (Sardaigne NordOccidentale). Implications paléogéographiques. Comptes Rendus Academie des Sciences Paris 296, 1709-1802.

Gomez, J.J., Fernandez-Lopez, S.R. (2006): The Iberian Middle Jurassic carbonate-platform system: Synthesis of the palaeogeographic elements of its eastern margin (Spain). Palaeogeography, Palaeoclimatology, Palaeoecology 236, 190-205. doi: 10.1016/j.palaeo.2005.11.008

Jadoul, F., Lanfranchi, A., Berra, F., Erba, E., Casellato, C.E., Cherchi, A., Simone, L., Schroeder, R., Carannante, G., Ibba, A. (2010): I sistemi carbonatici giurassici della Sardegna orientale (Golfo di Orosei) ed eventi deposizionali nel sistema carbonatico giurassico-cretacico della Nurra (Sardegna nord-occidentale). Periodico semestrale dell'ISPRA - Servizio geologico d'Italia e della Società Geologica Italiana. Geological Field Trip, Vol. 2. N. 2.1, pp 122. DOI: 10.3301/ GFT.2010.02

Kukal, Z. (ed.) (1990): The rate of erosion. In: The rate of geological processes. Special issue, Earth Science Review 28, 143-176.

Lanfranchi, A., Berra, F., Jadoul, F. (2011): Compositional changes in sigmoidal carbonate clinoforms (Late Tithonian, eastern Sardinia, Italy): insights from quantitative microfacies analyses. Sedimentology 58, 2039-2060. DOI: 10.1111/j.1365-3091.2011.01250.x

Léonide, P., Floquet, M., Villier, L. (2007); Interaction of tectonics, eustasy, climate and carbonate production on the sedimentary evolution of an early/middle Jurassic extensional basin (Southern Provence Subbasin, SE France). Basin Research 19, 125-152. doi: 10.1111/j.13652117.2007.00316.x

Lualdi, A. (1985): Elementi di correlazione di serie mediotriassiche del Brianzonese s.s., brianzonese ligure e prepiemontese. Rendiconti della Società Geologica Italiana, 8, 43-46.

Lualdi, A. (1994): I calcari di Rio di Nava (Dogger Brianzonese ligure): inquadramento stratigrafico e sedimentologico. Boll Soc Geol It 113, 501-520.

Marini, C. (1984): Le concentrazioni residuali post-erciniche di $\mathrm{Fe}$ dell'Ogliastra (Sardegna orientale): contesto geologico e dati mineralogici. Rendiconti della Società Italiana di Mineralogia e Petrografia 39, 229-238.

Marini, C., Mattias, P., Medici, C., Sistu, G., Uras, I. (1991): The claystone deposits in the mining district of Sarcidano (Central Sardinia): ore and technological aspects. Associazione Mineraria Subalpina 28, 89-106.

Masini, E., Manatschal, G., Mohn, G. (2013): The Alpine Tethys rifted margins: reconciling old and new ideas to understand the stratigraphic architecture of magma-poor rifted margins. Sedimentology 60, 174196. DOI: $10.1111 /$ sed. 12017

Passeri, L., Ciarapica, G., Reggiani, L., Rutledge, D.C. (2014): The significance of Longobucco Unit (Calabria-Peloritani Arc) in the evolution of the Ionian and Alpine Oceans. Bollettino della Società Geologica Italiana 133, 249-270. DOI: 10.3301/IJG.2014.07

Peybernés, B., Cugny, P., Fondecave-Wallez, M.J. (2000): Le problème de la limite Crétacé-Tertiaire en Corse du Sud. Bulletin Societé géologique de France 171, 451-459.

Peybernès, B., Durand-Delga, M., Rossi, P., Cugny, P. (2001): Nouvelles datations micropalèontologiques dans les sèquences intra- et postophiolites de la nappe de Balagne (Corse) et essai de reconstitution d'un segment de la marge occidentale de l'ocèan Liguro-Pièmontais. Eclogae Geologicae Helvetiae 94(1), 95-105.

Philippe, M., Thévenard, F., Barale, G., Ferry, S., Guignard, G. (1998): Middle Bathonian flora and phytocoenoses of France. Palaeogeogra- phy, Palaeoclimatology, Palaeoecology 143, 135-158.

Pittau, P., Del Río, M., Funedda, A. (2008): Relationships between plant communities characterization and basin formation in the Carboniferous-Permian of Sardinia. Bollettino della Società Geologica Italiana 127, 637-653.

Rees, P.M., Ziegler, A.M., Valdes, P.J. (2000): Jurassic phytogeography and climates: new data and model comparisons. In: Huber, B.T., Macleod, K.G., Wing, S.L. (eds.), Warm climates in earth history. Cambridge Univ. Press, 297-318.

Ronchi, A., Sarria, E., Broutin, J. (2008): The "Autuniano Sardo": basic features for a correlation through the Western Mediterranean and $\mathrm{Pa}$ leoeurope. Bollettino della Società Geologica Italiana 127, 655-681.

Rodríguez-Pascua, M.A., Calvo, J.P., De Vicente, G., Gómez-Gras, D. (2000): Soft-sediment deformation structures interpreted as seismites in lacustrine sediments of the Prebetic Zone, SE Spain, and their potential use as indicators of earthquake magnitudes during the Late Miocene. Sedimentary Geology 135, 117-135.

Santantonio, M. (1993): Facies associations and evolution of pelagic carbonate platform/basin systems: examples from the Italian Jurassic. Sedimentology 40,1039-1067.

Santantonio, M. (2012): Mesozoic evolution of the Caloveto Group, NE Calabria. Rendiconti Ondine della Società Geologica Italiana 21, 295-297.

Santantonio, M., Fabbi, S., Aldega, L. (2016): Mesozoic architecture of a tract of the European-Iberian continental margin: insights from preserved submarine palaeotopography in the Longobucco basin (Calabria, Southern Italy). Sedimentary Geology 331, 94-113. DOI. org/10.1016/j.sedgeo.2015.10.010

Scanu, G.G., Kustatscher, E., Pittau, P. (2014): The Jurassic flora of Sardinia - A new piece in the palaeobiogeographic puzzle of the Middle Jurassic. Review of Paleobotany and Palynology, 1-26, DOI. org/10.1016/j.revpalbo.2014.08.008

Stampfli, G.M. (1993): Le Briançonnais, terrain exotique dans les Alpes? Eclogae Geologicae Helvetiae 86, 1-45.

Stampfli, G.M. (2000): Tethyan oceans. In: Bozkurt, E., Winchester, J.A. and Piper, J.D.A. (eds), Tectonics and Magmatism in Turkey and the Surrounding Area. Geological Society, London, Special Publication 173, pp. 1-23.

Suárez-González, P., Quijada, I.E., Benito, M.I., Mas, R. (2015): Sedimentology of ancient coastal wetlands: insight from a Cretaceous multifaceted depostional system. Journal of Sedimentary Research 85, 95-117. DOI:org/10.2110/jsr.2015.07

Vai, G.B. (2001): Basement and early pre-Alpine history. In: Vai G.B. and Martini I.P. (eds.), Anatomy of an Orogen: the Apennines and Adjacent Mediterranean Basins. Kluwer Academic, Dordrecht, 121-150

Vardabasso, S. (1959): Il Mesozoico epicontinentale della Sardegna. Rendiconti di Scienze Fisiche, Matematiche e Naturali 27, 178-184.

Young, J.R., Tealec, T., Bown, P.R. (1986): Revision of the stratigraphy of the Longobucco Group (Liassic, southern Italy); based on new data from nannofossils and ammonites. Eclogae Geologicae Helvetiae 79, 117-135.

Zattin, M., Massari, F., Dieni, I. (2008): Thermochronological evidence for Mesozoic-Tertiary tectonic evolution in the eastern Sardinia. Terra Nova 20, 469-474. DOI: 10.1111/j.1365-3121.2008.00840.x

Ziegler, P.A. (1990): Geological Atlas of Western and Central Europe. 2 Vol. Shell Internationale Petroleum Maatschappij. B.V, 242 pp, 56 maps. 